\title{
The Economic Progress of African Americans in Urban Areas: A Tale of 14 Cities
}

\author{
Dan A. Black, Natalia A. Kolesnikova, and Lowell J. Taylor
}

\begin{abstract}
How significant was the economic progress of African Americans in the United States between 1970 and 2000? In this paper the authors examine this issue for black men 25 to 55 years of age who live in 14 large U.S. metropolitan areas. They present evidence that significant racial disparities remain in education and labor market outcomes of black and white men, and they discuss changes in industrial composition, migration, and demography that might have contributed to the stagnation of economic progress of black men between 1970 and 2000. In addition, the authors show that there was no progress in the financial well-being of black children, relative to white children, between 1970 and 2000. (JEL J15, J31, J71, R23)
\end{abstract}

Federal Reserve Bank of St. Louis Review, September/October 2010, 92(5), pp. 353-79.

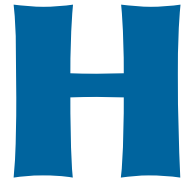

ow significant was the economic progress of African Americans in the United States between 1970 and 2000 ? The common perception is that inequality between races has decreased. In 1954, the Supreme Court's decision in the famous Brown v. Board of Education case proclaimed racial segregation of public schools unconstitutional. It paved the way for the Civil Rights Act of 1964, which outlawed racial segregation in schools and the workplace, among other provisions. By making racial discrimination illegal, the Act opened doors to better education, including higher education, and offered greater employment opportunities to African Americans.

This progress is undeniable, but questions remain: Did these societal changes translate into economic changes as well? Did earnings of blacks increase relative to earnings of whites? Did labor force attachment of blacks become more secure? How much did educational attainment and skill acquisition improve? Did the economic well-being of black children improve?

Most of the previous research on these topics was done on a national level. ${ }^{1}$ Such studies, at most, "control for" the geographic region (South, Northeast, Midwest, etc.) and/or whether a person resides in an urban/rural area. This paper, however, examines and compares various aspects of African-American progress in labor markets between 1970 and 2000 across large U.S. cities. Analysis on a city rather than national level addresses two issues: First, cities in the United States vary widely in their characteristics, including labor market conditions and industrial structure. Second, and more importantly, the history of the black population varies among the different regions of the country. These differences warrant a separate look at each city-Memphis and Detroit,

1 A very good overview of existing studies is presented in Altonji and Blank (1999).

Dan A. Black is a professor of economics and deputy dean at the Harris School of the University of Chicago and a senior fellow at the National Opinion Research Center. Natalia Kolesnikova is an economist at the Federal Reserve Bank of St. Louis. Lowell J. Taylor is a professor of economics at Carnegie Mellon University and a senior fellow at the National Opinion Research Center. The authors thank Yang Liu for invaluable research assistance.

(C) 2010, The Federal Reserve Bank of St. Louis. The views expressed in this article are those of the author(s) and do not necessarily reflect the views of the Federal Reserve System, the Board of Governors, or the regional Federal Reserve Banks. Articles may be reprinted, reproduced, published, distributed, displayed, and transmitted in their entirety if copyright notice, author name(s), and full citation are included. Abstracts, synopses, and other derivative works may be made only with prior written permission of the Federal Reserve Bank of St. Louis. 
for instance-to distinguish between them and thus better analyze changes in individual economic conditions of blacks.

Finally, a recent study by Black et al. (2009) demonstrates that it is important to take into consideration geographic location when studying racial differences. Performing analysis on a national level masks underlying trends in local labor markets. ${ }^{2}$ The study shows, in particular, that a failure to account for city-specific differences in black-white wage gaps results in a significant (about 50 percent) overestimation of black-white wage-gap conversion. In many local labor markets, especially high-productivity, highwage markets, the black-white wage gap essentially stayed the same over the years. But as more and more black men moved into high-wage cities, the national black-white wage gap has decreased dramatically even though there was little change in each particular market. The reason for the seeming black-white wage convergence was not only a change in labor markets but simply a redistribution of black population from low-wage to highwage markets-something that would not be apparent if looking only at national averages.

It seems reasonable, therefore, to document economic progress of African Americans in the context of a specific labor market and then compare the progress across cities. Performing such analysis is the goal of this paper. ${ }^{3}$

\section{DATA DESCRIPTION}

In particular, we study African-American progress in 14 metropolitan statistical areas (MSAs; as defined by the Census Bureau ${ }^{4}$ ) from 1970 to 2000. In what follows, we use "MSA" and "city" interchangeably. We use 1970 through 2000

2 Black et al. (2009) also show that in the presence of location-specific wages and prices, a racial wage gap is the same across locations only in the case of very specific (and usually unrealistic) preferences.

3 In this paper we concentrate on documenting city-specific changes in various measures of economic and social conditions of African Americans, leaving the explanation of the observed changes and differences in the observed changes to our future research.

4 The general concept of an MSA is that of a central city and its adjacent communities having a high degree of economic and social integration. decennial U.S. Census data provided by the Integrated Public Use Microdata Series ${ }^{5}$ (IPUMS). The 14 cities in the sample were chosen based on having at least 700 black respondents in the IPUMS 1970 Census data. They are the Atlanta, Baltimore, Chicago, Cleveland, Detroit, Houston, Los Angeles, Memphis, New Orleans, New York, Philadelphia, St. Louis, San Francisco, and Washington, D.C., MSAs. ${ }^{6,7}$

In this paper we restrict the analysis to black and non-Hispanic white men of prime working age -25 to 55 years old. ${ }^{8}$ For each respondent in the sample, the data provide a wealth of information, including age, educational attainment, employment status, income, industry and occupation of employment, class of worker, and marital status. ${ }^{9}$

An important concern with the Census data is that respondents occasionally choose not to answer some questions. Those who did not answer questions related to the issues of this study were not included in the sample. Also, the respondents who lived in institutions (such as correctional facilities) and non-institutional group quarters (such as military barracks) were not included. Thus, the final sample consists of black and white men of prime working age who were not in the military and not incarcerated. Increasing rates of incarceration of black men is an alarming trend

5 See Ruggles et al. (2010).

6 There are no MSA identifiers in the 1960 IPUMS Census data, which makes it impossible to extend this analysis to earlier years. The smallest geographic unit in the 1960 IPUMS Census data is a state.

7 In 1970 a quite large proportion, about 43 percent, of black men of prime working age, 25 to 55 years old, lived in these 14 MSAs. Nevertheless, it is worth pointing out that the results of this paper should not be taken as a picture of the economic progress of black men in the United States as a whole. Rather, the paper focuses on economic progress of black men in large urban areas.

8 A similar investigation of the economic progress of black women is equally interesting but presents additional challenges. There has been a significant change in the labor force participation of black and white women over the period studied. In addition, women's attachment to the labor force tends to be weaker than men's because women often exit the labor force for childbearing and child care. This makes a direct comparison of white and black women's labor market outcomes even more complicated. It is an important topic we plan to pursue in future research.

9 A detailed description of the variables is provided in Appendix 1. 


\section{Table 1}

\section{Black-White Weekly Wage Ratios for Men (percent)}

\begin{tabular}{lllll} 
MSA & $\mathbf{1 9 7 0}$ & $\mathbf{1 9 8 0}$ & $\mathbf{1 9 9 0}$ & $\mathbf{2 0 0 0}$ \\
\hline South & & & & \\
Houston & 65 & 76 & 74 & 72 \\
Memphis & 63 & 73 & 71 & 78 \\
Atlanta & 62 & 75 & 75 & 78 \\
New Orleans & 63 & 73 & 74 & 75 \\
Washington, D.C. & 72 & 80 & 81 & 83 \\
East & & & & \\
New York & 75 & 76 & 77 & 78 \\
Philadelphia & 79 & 77 & 77 & 77 \\
Baltimore & 71 & 78 & 76 & 79 \\
Midwest & & & & \\
St. Louis & 74 & 77 & 73 & 77 \\
Cleveland & 76 & 82 & 80 & 77 \\
Chicago & 75 & 75 & 74 & 74 \\
Detroit & 81 & 83 & 81 & 78 \\
West & & & & \\
Los Angeles & 74 & 77 & 81 & 80 \\
San Francisco & 78 & 79 & 82 & 80
\end{tabular}

NOTE: The table is adapted from Black et al. (2009). For convenience, log differences of positive weekly wages of black and white men were converted into ratios.

and a subject of many studies. ${ }^{10}$ It is not a focus of this paper, however.

\section{CHANGES IN RELATIVE WAGES AND ANNUAL EARNINGS}

Many studies concentrate on wages as a measure of earnings. It is a logical approach because a wage is a price that labor markets put on a unit of labor of a certain skill level. In this case, a

\footnotetext{
${ }^{10}$ See, for example, Western (2006) and Charles and Luoh (forthcoming). Charles and Luoh document an astonishing increase of incarceration rates of black men 25 to 35 years old between 1970 and 2000. For example, in 2000 almost 30 percent were incarcerated in New Mexico, 23 percent in Wisconsin and Minnesota, and 22 percent in Arizona. In 2000, their lowest incarceration rate was 7 percent, in Washington, D.C., whereas state incarceration rates of white men ranged from 0.8 and 3.2 percent.
}

\section{Table 2}

Black-White Annual Earnings Ratios for Men (percent)

\begin{tabular}{lllll} 
MSA & $\mathbf{1 9 7 0}$ & $\mathbf{1 9 8 0}$ & $\mathbf{1 9 9 0}$ & $\mathbf{2 0 0 0}$ \\
\hline South & & & & \\
Houston & 59 & 67 & 61 & 59 \\
Memphis & 52 & 60 & 56 & 66 \\
Atlanta & 56 & 64 & 66 & 66 \\
New Orleans & 57 & 63 & 60 & 65 \\
Washington, D.C. & 62 & 71 & 70 & 72 \\
East & & & & \\
New York & 68 & 64 & 60 & 58 \\
Philadelphia & 72 & 63 & 63 & 61 \\
Baltimore & 66 & 65 & 65 & 67 \\
Midwest & & & & \\
St. Louis & 66 & 63 & 59 & 62 \\
Cleveland & 70 & 70 & 62 & 63 \\
Chicago & 69 & 62 & 56 & 55 \\
$\quad$ Detroit & 71 & 66 & 60 & 63 \\
West & & & & \\
Los Angeles & 66 & 66 & 64 & 62 \\
San Francisco & 68 & 63 & 62 & 62
\end{tabular}

NOTE: Authors' calculations. See Appendix 2 for details. The calculation includes individuals with zero earnings.

decrease in the black-white wage gap means labor markets' valuations of black and white labor converge. It also indicates the convergence of skill levels of black and white workers.

However, differences in wages is only one of the labor market characteristics that potentially contribute to racial economic disparity. Other important factors include labor force participation, unemployment, and underemployment. To better assess the economic progress of blacks, we consider a different measure-annual earnings, which take into consideration both wages and labor force attachment. Analyzing annual earnings instead of wages allows a better assessment of an individual's overall economic well-being.

Table 1, adapted from Black et al. (2009), shows in percent form a ratio of the average weekly wages of black men to those of white men. 
From 1970 to 2000 , the relative weekly wages of black men increased in all but three cities (Philadelphia, Chicago, and Detroit). For example, in 1970 in Houston, black men earned on average 65 percent of the weekly wages of white men. The ratio increased to 72 percent in 2000. Atlanta experienced the largest increase, from 62 percent in 1970 to 78 percent in 2000-a 16-percentagepoint increase. In Philadelphia, Chicago, and Detroit the relative wages of black men decreased between 1970 and 2000, but only slightly: from 79 percent to 77 percent in Philadelphia, from 75 percent to 74 percent in Chicago, and from 81 percent to 78 percent in Detroit.

Table 2 provides a summary of changes of black-white annual earnings ratios in the 14 cities from 1970 to $2000 .{ }^{11}$ The picture of economic progress of black men is much less bright when we consider their annual earnings. In contrast to weekly wages, relative annual earnings of black men declined in most cities. In southern cities that did experience an increase in relative annual earnings of black men, most of the progress occurred between 1970 and 1980, with no significant changes after that. ${ }^{12}$ In Chicago, where their relative annual earnings fell the most (14 percentage points), black men were earning 69 percent of white men's annual income in 1970 but only 55 percent in 2000. Most of midwestern and eastern cities in the sample experienced a similar decline. Interestingly, the magnitude and timing of the declines vary across cities. In New York, for example, the overall decrease of 10 percentage points was spread somewhat equally over the three decades. In Philadelphia, the almost 10percentage-point drop between 1970 and 1980 was followed by virtually no change after 1980 . In Cleveland, the largest decrease occurred between 1980 and 1990. In Detroit and St. Louis, two decades of regress were followed by a 3percentage-point increase between 1990 and 2000. In Baltimore and Los Angeles, in contrast, the ratio remained fairly stable over the three decades.

\footnotetext{
${ }^{11}$ See Appendix 2 for details of the estimation.

${ }^{12}$ Memphis was an exception. There, the ratio declined by 4 percentage points in 1980-90 but then increased by 10 percentage points in 1990-2000.
}

\section{CHANGES IN LABOR FORCE PARTICIPATION}

The main reason for the discrepancy between the two measures of economic progress of black men from 1970 to 2000 is the labor force attachment of black men. During that time, black men experienced a significant decline in their average annual weeks of work. (This, of course, affected their average annual earnings.) Figure 1 illustrates this fact and Table 3 reports corresponding numbers. ${ }^{13}$ The average decreased in every city, in some cases by as much as 25 percent. In 2000 , black men on average worked only 33 weeks per year in San Francisco (down from 42 in 1970), 34 weeks in Los Angeles and Chicago (down from 43 and 45, respectively, in 1970), and 35 weeks in Detroit (down from 45 in 1970). In contrast, in 2000, Atlanta and Washington, D.C., both experienced the highest average number of weeks worked: 41. But even this number is not higher than the average in any of the 14 cities in $1970 .{ }^{14}$

Figure 2 and Table 4 show that, in contrast, the weekly hours of work of black men stayed remarkably stable between 1970 and 2000, with relatively small increases in some cities and decreases in others. ${ }^{15,16}$ The low average in 2000 implies not only underemployment for many black men but also that many did not work at all, which drives the average numbers down.

To better assess changes in the labor force participation of black men between 1970 and 2000, Table 5 reports the proportion of black men employed, unemployed, or not in the labor force.

\footnotetext{
${ }^{13}$ See Appendix 2 for details of the estimation. It describes, in particular, an imputation technique for 1970 data.

${ }^{14}$ In comparison, white men experienced only a small decline in their average annual weeks of work over the same period in all 14 cities: from 47 to 49 weeks in 1970 to 43 to 48 weeks in 2000. The largest declines, from 47 weeks in 1970 to 43 weeks in 2000, occurred in New York and Los Angeles. In the rest of the cities, white men worked on average 1 to 2 weeks less per year in 1970 than in 2000. Detailed results are available from the authors upon request.

${ }^{15}$ See Appendix 2 for details of the estimation. It describes, in particular, an imputation technique for 1970 data.

${ }^{16}$ Weekly hours of work of white men increased slightly over the same period in all 14 cities: from 39 to 43 hours per week in 1970 to 40 to 45 hours per week in 2000. Detailed results are available from the authors upon request.
} 


\section{Figure 1}

\section{Average Annual Weeks of Work of Black Men: 1970-2000}

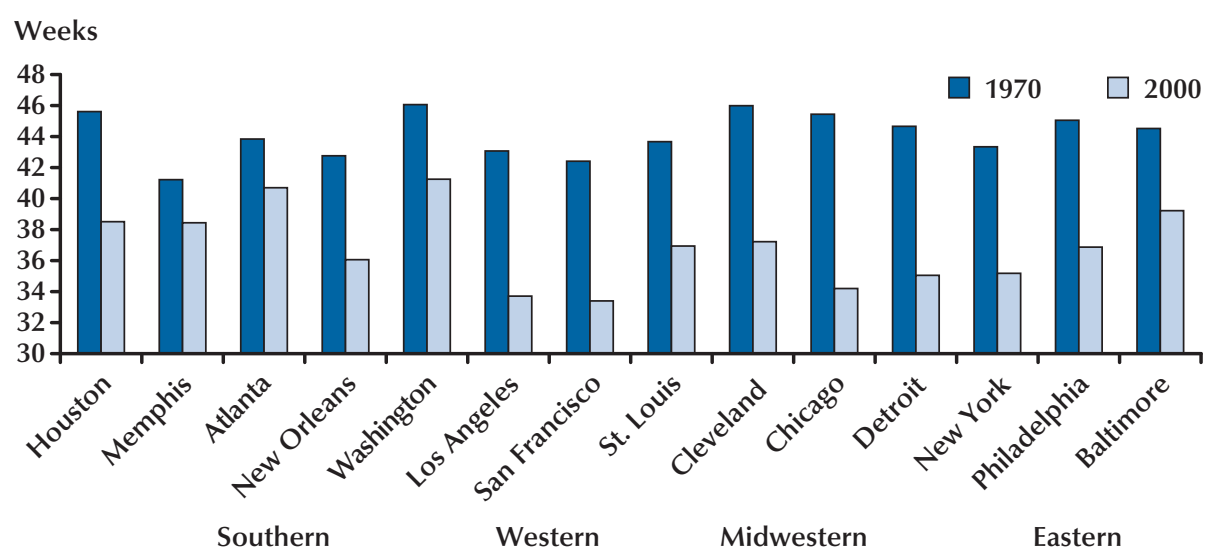

The table shows two main changes between 1970 and 2000: decreases in the proportion of black men employed and increases in the proportion of black men not in the labor force. The table shows also that in a number of cities, after the unemployment rate rose in 1980 and 1990, it decreased in 2000 while the proportion of black men not in the labor force increased. This observed trend seems consistent with a "discouraged workers" explanation: When the unemployment rate is high for a prolonged period, workers looking for jobs give up and opt out of the labor force and thus are not counted as unemployed. ${ }^{17}$ For example, consider Chicago in 1970: 88 percent of black men were employed, 4 percent were unemployed, and 8 percent were not in the labor force. By 1980, their employment dropped to 75 percent, their unemployment rate rose to 10 percent, and 14 percent were not in the labor force. Things kept getting

${ }^{17}$ There is evidence that access to personal job-search networks is very important. Holzer (1987) finds that "informal methods of search...account for 87-90 percent of the difference in youth employment probabilities between blacks and whites" (p. 451). Calvó-Armengol and Jackson (2004) use a similar social-networking approach to argue that the probability of obtaining a job decreases with the length of time one remains unemployed. They also examine related inequality. In particular, they show that "if one group starts with worse employment status, then that group's drop-out rate will be higher and their employment prospects will be persistently below that of the other group" (p. 426).
Table 3

Average Annual Weeks of Work of Black Men

\begin{tabular}{lllll} 
MSA & $\mathbf{1 9 7 0}$ & $\mathbf{1 9 8 0}$ & $\mathbf{1 9 9 0}$ & $\mathbf{2 0 0 0}$ \\
\hline South & & & & \\
$\quad$ Houston & 46 & 41 & 38 & 39 \\
$\quad$ Memphis & 41 & 39 & 39 & 38 \\
$\quad$ Atlanta & 44 & 40 & 41 & 41 \\
$\quad$ New Orleans & 43 & 39 & 35 & 36 \\
$\quad$ Washington, D.C. & 46 & 41 & 42 & 41 \\
East & & & & \\
$\quad$ New York & 43 & 37 & 36 & 35 \\
$\quad$ Philadelphia & 45 & 36 & 37 & 37 \\
$\quad$ Baltimore & 45 & 39 & 39 & 39 \\
Midwest & & & & \\
$\quad$ St. Louis & 44 & 38 & 36 & 37 \\
$\quad$ Cleveland & 46 & 38 & 34 & 37 \\
$\quad$ Chicago & 45 & 37 & 35 & 34 \\
$\quad$ Detroit & 45 & 35 & 33 & 35 \\
West & & & & \\
$\quad$ Los Angeles & 43 & 37 & 35 & 34 \\
$\quad$ San Francisco & 42 & 35 & 32 & 33 \\
$\quad$ United States & 44 & 39 & 38 & 38
\end{tabular}

NOTE: Authors' calculations. See Appendix 2 for details. The calculation includes individuals with zero weeks of work. 
Figure 2

Average Weekly Hours of Work of Black Men: 1970-2000

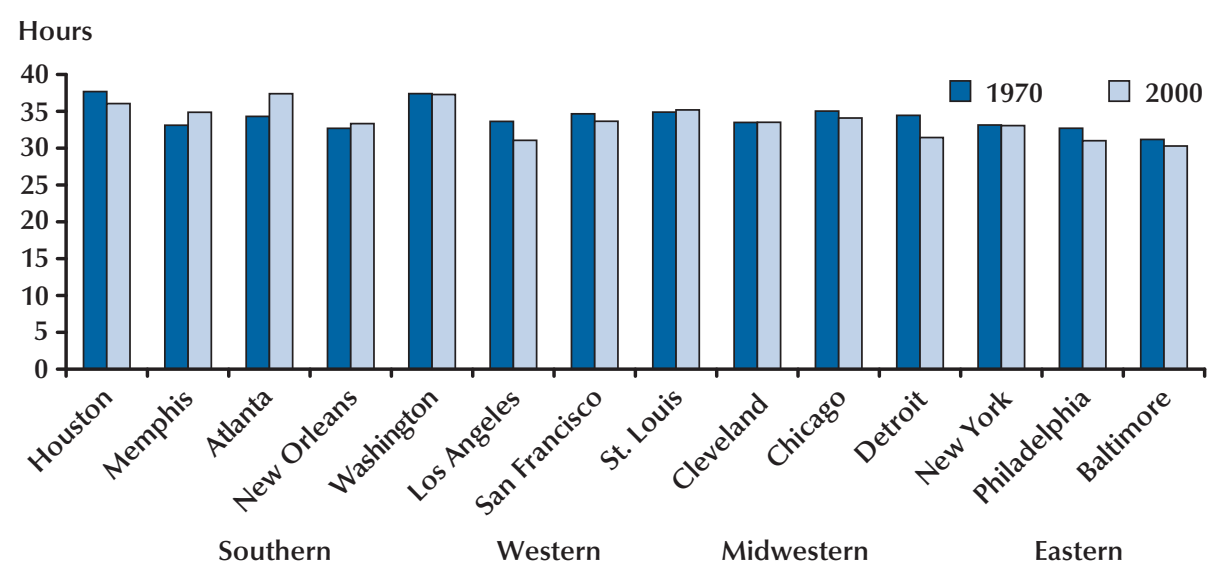

Table 4

Average Weekly Hours of Work of Black Men

\begin{tabular}{lllll} 
MSA & $\mathbf{1 9 7 0}$ & $\mathbf{1 9 8 0}$ & $\mathbf{1 9 9 0}$ & $\mathbf{2 0 0 0}$ \\
\hline South & & & & \\
Houston & 38 & 36 & 35 & 36 \\
Memphis & 33 & 34 & 34 & 35 \\
Atlanta & 34 & 35 & 37 & 37 \\
New Orleans & 33 & 34 & 33 & 33 \\
Washington, D.C. & 37 & 36 & 37 & 37 \\
East & & & & \\
New York & 34 & 31 & 32 & 31 \\
Philadelphia & 35 & 32 & 34 & 34 \\
$\quad$ Baltimore & 35 & 34 & 35 & 35 \\
Midwest & & & & \\
St. Louis & 33 & 33 & 33 & 34 \\
Cleveland & 35 & 34 & 31 & 34 \\
Chicago & 34 & 32 & 32 & 31 \\
$\quad$ Detroit & 33 & 32 & 31 & 33 \\
West & & & & \\
Los Angeles & 33 & 33 & 32 & 31 \\
San Francisco & 31 & 31 & 29 & 30 \\
United States & 34 & 34 & 34 & 34
\end{tabular}

NOTE: Authors' calculations. See Appendix 2 for details. The calculation includes individuals with zero weekly hours of work. worse and by 1990, 71 percent were employed, 13 percent were unemployed, and 16 percent were not in the labor force. In 2000, their employment rate decreased further, to 69 percent, yet their unemployment rate actually improved and decreased from 13 percent to 9 percent. The proportion of black men not in the labor force, however, rose to a staggering 22 percent. ${ }^{18} \mathrm{~A}$ similar pattern of changes can be observed in many other cities, including Houston, New Orleans, St. Louis, Cleveland, Detroit, and Philadelphia. In 2000, in 10 of the 14 cities, the proportion of black men not in the labor force was above 20 percent. This high level is observed even in cities where the unemployment rate was relatively stable at 7 to 9 percent, such as in Los Angeles and San Francisco.

In all cities except Atlanta, the employment rate of black men decreased by 11 to 19 percentage points between 1970 and 2000. Atlanta had a much smaller drop of only 6 percentage pointsfrom 87 percent to 81 percent. In 2000, Atlanta had the highest employment and lowest unemployment rates of black men.

To sum up, between 1970 and 2000 in 14 major urban areas in the United States, black men

\footnotetext{
18 To put the numbers in the right context, it is worth remembering that the sample consists of black men of prime working age (25 to 55 years old) who are not incarcerated and not in the military.
} 


\section{Table 5}

\section{Employment Status of Black Men (percent)}

\begin{tabular}{|c|c|c|c|c|c|c|c|c|c|}
\hline MSA & 1970 & 1980 & 1990 & 2000 & MSA & 1970 & 1980 & 1990 & 2000 \\
\hline South & & & & & Midwest & & & & \\
\hline Houston & & & & & St. Louis & & & & \\
\hline Has a job & 92 & 89 & 79 & 77 & Has a job & 83 & 74 & 71 & 72 \\
\hline Unemployed & 2 & 3 & 10 & 6 & Unemployed & 8 & 13 & 13 & 7 \\
\hline Not in labor force & 6 & 8 & 11 & 17 & Not in labor force & 10 & 13 & 16 & 21 \\
\hline Memphis & & & & & Cleveland & & & & \\
\hline Has a job & 85 & 79 & 79 & 74 & Has a job & 85 & 75 & 68 & 72 \\
\hline Unemployed & 3 & 9 & 7 & 6 & Unemployed & 6 & 11 & 13 & 8 \\
\hline Not in labor force & 11 & 13 & 14 & 20 & Not in labor force & 9 & 14 & 18 & 20 \\
\hline Atlanta & & & & & Chicago & & & & \\
\hline Has a job & 87 & 82 & 84 & 81 & Has a job & 88 & 75 & 71 & 69 \\
\hline Unemployed & 3 & 7 & 7 & 4 & Unemployed & 4 & 10 & 13 & 9 \\
\hline Not in labor force & 10 & 11 & 9 & 15 & Not in labor force & 8 & 14 & 16 & 22 \\
\hline New Orleans & & & & & Detroit & & & & \\
\hline Has a job & 84 & 80 & 71 & 71 & Has a job & 86 & 65 & 66 & 69 \\
\hline Unemployed & 4 & 6 & 10 & 6 & Unemployed & 7 & 19 & 15 & 8 \\
\hline Not in labor force & 12 & 14 & 18 & 23 & Not in labor force & 7 & 16 & 19 & 23 \\
\hline Washington, D.C. & & & & & West & & & & \\
\hline Has a job & 92 & 85 & 87 & 81 & Los Angeles & & & & \\
\hline Unemployed & 1 & 5 & 5 & 5 & Has a job & 83 & 78 & 76 & 70 \\
\hline Not in labor force & 7 & 9 & 8 & 14 & Unemployed & 7 & 8 & 9 & 9 \\
\hline East & & & & & Not in labor force & 10 & 14 & 15 & 21 \\
\hline New York & & & & & San Francisco & & & & \\
\hline Has a job & 86 & 77 & 76 & 71 & Has a job & 83 & 76 & 73 & 71 \\
\hline Unemployed & 3 & 8 & 9 & 7 & Unemployed & 7 & 9 & 7 & 7 \\
\hline Not in labor force & 10 & 15 & 15 & 22 & Not in labor force & 11 & 15 & 21 & 22 \\
\hline Philadelphia & & & & & United States & & & & \\
\hline Has a job & 86 & 74 & 76 & 72 & Has a job & 87 & 79 & 77 & 74 \\
\hline Unemployed & 5 & 10 & 10 & 8 & Unemployed & 4 & 8 & 9 & 6 \\
\hline Not in labor force & 9 & 16 & 14 & 21 & Not in labor force & 9 & 13 & 14 & 19 \\
\hline \multicolumn{10}{|l|}{ Baltimore } \\
\hline Has a job & 87 & 78 & 78 & 74 & & & & & \\
\hline Unemployed & 4 & 8 & 8 & 7 & & & & & \\
\hline Not in labor force & 9 & 14 & 14 & 19 & & & & & \\
\hline
\end{tabular}


experienced significant decreases in their rates of employment while their rates of unemployment and the number of those opting out of the labor force increased. As a result, their average annual weeks of work decreased dramatically, as did their annual earnings relative to those for white men.

Why did this happen? What were the contributing factors? To begin answering these important questions we need to take a closer look at changes in labor markets and the social structure.

\section{CHANGES IN EDUCATIONAL ATTAINMENT}

A big part of black-white economic convergence is attributed to a significant increase in educational attainment levels of blacks over the past century. As reported in Table 6, we consider five major educational categories: less than high school, high school diploma (or General Educational Development [GED] certificate), some college but no bachelor's degree, bachelor's degree, higher than a bachelor's degree. (For comparison, Table 7 provides similar statistics for white men.)

There are several main points worth noting.

First, in 1970 in most cities, the majority of black men did not have a high school diploma. The situation was the worst in the South. In Memphis, 77 percent of black men who were 25 to 55 years old in 1970 did not have a high school diploma, only 7 percent had some college experience, and only 3 percent had a bachelor's degree or higher. In New Orleans, 70 percent did not have a high school diploma. The situation was much better in the West: In Los Angeles and San Francisco, only 38 and 42 percent, respectively, did not have a high school diploma. Washington, D.C., also had a relatively small proportion of black men without a high school diploma in 1970: 47 percent.

Second, the educational attainment of black men progressed significantly between 1970 and 2000. In 2000 in New Orleans, only 26 percent (down from 70 percent in 1970) did not have a high school diploma. This proportion is even smaller in the other 13 cities. The proportion of black men who went to college significantly increased as well, although less than half of those who pursued their education beyond high school received a bachelor's degree or higher.

Third, despite their progress, black men still lag far behind white men in educational attainment. Figure 3 illustrates this point for black men in the 14 cities in 1970 and 2000. The top panel shows the fractions with no high school diploma, the middle panel the fractions with a high school diploma (or GED certificate), and the bottom panel the fractions with at least a bachelor's degree.

Figure 3 makes it easy to see that the proportion of black men without a high school diploma dropped considerably between 1970 and 2000 in all cities. The progress was more significant in the southern cities than in the midwestern and eastern cities. However, in all the cities except Atlanta, the rates of black men not completing high school are still at least double those of white men. In 2000, in all cities except New Orleans, less than 10 percent of white men did not have a high school diploma; in contrast, in 9 of the 14 cities at least 19 percent of black men did not have a high school diploma.

Given a sharp rise in the demand for educated labor over the past several decades, it is particularly alarming that only a very small number of black men had a bachelor's or higher degree even by 2000 . Washington, D.C., and Atlanta had the largest proportions with at least a bachelor's degree: 26 and 23 percent, respectively. However, almost twice as many white men in these cities, 58 and 44 percent, respectively, had at least a bachelors' degree. In Memphis, New Orleans, St. Louis, Cleveland, and Detroit, only 12 to 14 percent of black men had graduated from college. In San Francisco, 62 percent of white men had at least a bachelor's degree, yet only 23 percent of black men did.

Tables 6 and 7 and Figure 3 demonstrate that black men, despite their important gains in educational attainment between 1970 and 2000, still do not have levels of education anywhere near those of white men. Of additional concern is the quality of education that blacks receive, especially in inner-city schools in major urban areas. Progress in educational attainment in itself, though, is not as important as a resulting black-white convergence in skill levels. It has been shown that black- 
white skill convergence stopped in the late 1980s. ${ }^{19}$

\section{DE-INDUSTRIALIZATION AND CHANGES IN INDUSTRIAL COMPOSITION}

Industrial composition changed considerably between 1970 and 2000, especially in manufacturing cities. De-industrialization hurt both blacks and whites, but blacks were more affected. One reason is that, as we discuss below, black men were more likely to be employed in manufacturing industries. Another is that black men on average have lower levels of educational attainment, which makes it harder for them to adapt to new labor market conditions and find new jobs in a different industry. Also, as more and more jobs require training beyond high school, black men are worse off than white men because of their relatively low education levels. ${ }^{20}$

Table 8 shows the changes from 1970 to 2000 in the distribution of all working men across industries. (Table 9 reports similar statistics for black men only.) The main story across the decades is a decline in manufacturing employment and a rise in service industry employment. The proportion of men employed in other industries changed very little. With the exception of Washington, D.C., where government jobs have historically dominated, employment of men in manufacturing dropped by at least 8 percentage points (as in New Orleans). In cities that were predominantly industrial, such as St. Louis, Cleveland, Chicago, Detroit, Philadelphia, and Baltimore, manufacturing employment fell by 17 to 20 percentage points. In 1970 in Detroit, for instance, 51 percent of men

\footnotetext{
${ }^{19}$ See Neal (2006) for an excellent discussion of the topic.

${ }^{20}$ Bound and Holzer (1993) show that the decline in manufacturing in the 1970s and 1980s reduced employment for both blacks and whites. They also find that blacks generally had larger employment declines than whites. Other studies (Bound and Freeman, 1992, for example) show similar results. Bound and Johnson (1992) find that during the 1980s the labor demand shifted dramatically toward high-skilled labor, which was a major cause of a huge increase in relative wages of highly educated workers.
}

worked in manufacturing. That number declined to 33 percent by 2000. Cleveland experienced a similar decrease, from 45 percent in 1970 to 26 percent in 2000.

As shown in Table 9, black men were more likely to be employed in manufacturing in 1970 and thus were more affected by de-industrialization. In 1970, 56 percent of black men in Detroit had manufacturing jobs, 47 percent in Cleveland, and 37 percent in Chicago. By 2000, these numbers had decreased by 30,26 , and 24 percentage points, respectively. More generally, in 1970 in 10 of 14 cities, manufacturing employed the largest proportion of black workers; by 2000, as a result of de-industrialization, manufacturing lost its leading role in all cities except Detroit. Even so, Detroit's proportion of black men employed in manufacturing still decreased from 56 percent in 1970 to 26 percent in 2000.

Not surprisingly, labor market conditions deteriorated more significantly in cities with a high manufacturing concentration. In cities with a more-diverse industrial mix, the results of deindustrialization were less dire. As previously noted, labor force participation of black men did not decrease nearly as dramatically in Atlanta and Washington, D.C., as in Chicago and Detroit.

\section{THE ROLE OF MIGRATION}

It is impossible to talk about changes in the local labor markets of these 14 cities without discussing underlying population changes. As Table 10 shows, most southern cities, especially Houston and Atlanta, were growing between 1970 and 2000. In contrast, eastern and midwestern cities were either declining or experiencing very slow growth well below the overall U.S. rate.

Table 11 documents changes in black population in the 14 cities and the United States from 1970 to 2000. It shows that the pattern of changes in these cities did not always follow the overall changes in the United States. For example, between 1970 and 1980, when New York City lost 9 percent of its population, black population there actually increased by 13 percent. Similar events occurred in other cities with declining 


\section{Table 6}

\section{Educational Attainment of Black Men (percent)}

\begin{tabular}{|c|c|c|c|c|c|c|c|c|c|}
\hline MSA & 1970 & 1980 & 1990 & 2000 & MSA & 1970 & 1980 & 1990 & 2000 \\
\hline South & & & & & Midwest & & & & \\
\hline Houston & & & & & St. Louis & & & & \\
\hline Less than high school & 63 & 31 & 23 & 16 & Less than high school & 59 & 37 & 26 & 20 \\
\hline HSD/GED & 22 & 35 & 31 & 30 & HSD/GED & 25 & 33 & 32 & 33 \\
\hline Some college, no degree & 10 & 20 & 28 & 34 & Some college, no degree & e 11 & 20 & 29 & 34 \\
\hline Bachelor's degree & 2 & 8 & 13 & 15 & Bachelor's degree & 2 & 6 & 9 & 10 \\
\hline Above a bachelor's & 3 & 7 & 5 & 5 & Above a bachelor's & 3 & 5 & 4 & 4 \\
\hline Memphis & & & & & Cleveland & & & & \\
\hline Less than high school & 77 & 44 & 29 & 22 & Less than high school & 55 & 35 & 29 & 20 \\
\hline $\mathrm{HSD} / \mathrm{GED}$ & 15 & 34 & 34 & 36 & HSD/GED & 33 & 41 & 35 & 37 \\
\hline Some college, no degree & e 4 & 14 & 27 & 30 & Some college, no degree & 8 & 16 & 27 & 30 \\
\hline Bachelor's degree & 2 & 5 & 8 & 10 & Bachelor's degree & 2 & 5 & 6 & 9 \\
\hline Above a bachelor's & 1 & 3 & 3 & 3 & Above a bachelor's & 2 & 4 & 4 & 4 \\
\hline Atlanta & & & & & Chicago & & & & \\
\hline Less than high school & 64 & 34 & 21 & 13 & Less than high school & 52 & 37 & 26 & 19 \\
\hline HSD/GED & 26 & 38 & 32 & 29 & HSD/GED & 31 & 34 & 29 & 28 \\
\hline Some college, no degree & e 5 & 15 & 28 & 34 & Some college, no degree & 11 & 20 & 32 & 35 \\
\hline Bachelor's degree & 2 & 8 & 14 & 17 & Bachelor's degree & 3 & 5 & 9 & 12 \\
\hline Above a bachelor's & 2 & 5 & 6 & 6 & Above a bachelor's & 2 & 4 & 4 & 5 \\
\hline New Orleans & & & & & Detroit & & & & \\
\hline Less than high school & 70 & 43 & 34 & 26 & Less than high school & 58 & 36 & 28 & 21 \\
\hline HSD/GED & 19 & 32 & 28 & 33 & HSD/GED & 30 & 36 & 30 & 34 \\
\hline Some college, no degree & e 7 & 16 & 26 & 29 & Some college, no degree & 7 & 19 & 31 & 32 \\
\hline Bachelor's degree & 3 & 5 & 8 & 9 & Bachelor's degree & 2 & 5 & 7 & 9 \\
\hline Above a bachelor's & 2 & 3 & 3 & 3 & Above a bachelor's & 3 & 4 & 4 & 5 \\
\hline Washington, D.C. & & & & & East & & & & \\
\hline Less than high school & 47 & 28 & 20 & 13 & New York & & & & \\
\hline HSD/GED & 33 & 36 & 30 & 29 & Less than high school & 51 & 33 & 30 & 22 \\
\hline Some college, no degree & e 9 & 19 & 28 & 31 & HSD/GED & 35 & 38 & 29 & 29 \\
\hline Bachelor's degree & 6 & 8 & 14 & 17 & Some college, no degree & 8 & 17 & 27 & 30 \\
\hline Above a bachelor's & 6 & 9 & 8 & 9 & Bachelor's degree & 3 & 6 & 10 & 13 \\
\hline West & & & & & Above a bachelor's & 3 & 5 & 5 & 6 \\
\hline Los Angeles & & & & & Philadelphia & & & & \\
\hline Less than high school & 38 & 21 & 18 & 15 & Less than high school & 56 & 36 & 28 & 19 \\
\hline $\mathrm{HSD} / \mathrm{GED}$ & 35 & 36 & 26 & 25 & HSD/GED & 31 & 41 & 36 & 38 \\
\hline Some college, no degree & 19 & 29 & 38 & 40 & Some college, no degree & 7 & 13 & 23 & 28 \\
\hline Bachelor's degree & 4 & 7 & 13 & 14 & Bachelor's degree & 3 & 5 & 9 & 11 \\
\hline Above a bachelor's & 4 & 7 & 6 & 6 & Above a bachelor's & 3 & 5 & 4 & 5 \\
\hline San Francisco & & & & & Baltimore & & & & \\
\hline Less than high school & 42 & 19 & 18 & 16 & Less than high school & 66 & 44 & 29 & 20 \\
\hline HSD/GED & 32 & 34 & 23 & 24 & HSD/GED & 23 & 32 & 32 & 34 \\
\hline Some college, no degree & 17 & 30 & 37 & 37 & Some college, no degree & 5 & 15 & 25 & 29 \\
\hline Bachelor's degree & 5 & 8 & 13 & 14 & Bachelor's degree & 4 & 4 & 9 & 11 \\
\hline Above a bachelor's & 4 & 9 & 9 & 9 & Above a bachelor's & 3 & 5 & 5 & 6 \\
\hline
\end{tabular}

NOTE: Authors' calculations. See Appendix 1 for details. HSD/GED, high school diploma or GED. 


\section{Table 7}

Educational Attainment of White Men (percent)

\begin{tabular}{|c|c|c|c|c|}
\hline MSA & 1970 & 1980 & 1990 & 200 \\
\hline \multicolumn{5}{|l|}{ South } \\
\hline \multicolumn{5}{|l|}{ Houston } \\
\hline Less than high school & 32 & 13 & 9 & 7 \\
\hline HSD/GED & 25 & 26 & 20 & 19 \\
\hline Some college, no degree & e 17 & 23 & 30 & 30 \\
\hline Bachelor's degree & 14 & 21 & 27 & 30 \\
\hline Above a bachelor's & 11 & 18 & 14 & 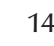 \\
\hline \multicolumn{5}{|l|}{ Memphis } \\
\hline Less than high school & 29 & 14 & 8 & 7 \\
\hline HSD/GED & 38 & 32 & 21 & 21 \\
\hline Some college, no degree & e 13 & 22 & 34 & 33 \\
\hline Bachelor's degree & 11 & 16 & 24 & 26 \\
\hline Above a bachelor's & 9 & 15 & 13 & 13 \\
\hline \multicolumn{5}{|l|}{ Atlanta } \\
\hline Less than high school & 31 & 16 & 9 & 0 \\
\hline HSD/GED & 28 & 27 & 20 & 20 \\
\hline Some college, no degree & e 17 & 21 & 28 & 27 \\
\hline Bachelor's degree & 14 & 20 & 29 & 30 \\
\hline Above a bachelor's & 9 & 16 & 14 & 14 \\
\hline \multicolumn{5}{|l|}{ New Orleans } \\
\hline Less than high school & 36 & 17 & 11 & 13 \\
\hline HSD/GED & 29 & 30 & 23 & 25 \\
\hline Some college, no degree & e 14 & 19 & 29 & 29 \\
\hline Bachelor's degree & 11 & 16 & 22 & 21 \\
\hline Above a bachelor's & 10 & 17 & 15 & 12 \\
\hline \multicolumn{5}{|l|}{ Washington, D.C. } \\
\hline Less than high school & 20 & 9 & 6 & 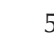 \\
\hline HSD/GED & 27 & 21 & 16 & 15 \\
\hline Some college, no degree & e 15 & 16 & 23 & \\
\hline Bachelor's degree & 14 & 20 & 29 & 31 \\
\hline Above a bachelor's & 24 & 33 & 27 & 27 \\
\hline
\end{tabular}

\section{West}

Los Angeles

$\begin{array}{lllll}\text { Less than high school } & 21 & 11 & 8 & 6\end{array}$

$\begin{array}{lllll}\text { HSD/GED } & 33 & 27 & 17 & 15\end{array}$

$\begin{array}{llll}\text { Some college, no degree } 22 & 27 & 34 & 33\end{array}$

$\begin{array}{lllll}\text { Bachelor's degree } & 11 & 16 & 24 & 28\end{array}$

$\begin{array}{lllll}\text { Above a bachelor's } & 13 & 19 & 16 & 17\end{array}$

San Francisco

$\begin{array}{lrrrr}\text { Less than high school } & 19 & 8 & 5 & 3 \\ \text { HSD/GED } & 32 & 25 & 13 & 10 \\ \text { Some college, no degree } & 20 & 25 & 30 & 25 \\ \text { Bachelor's degree } & 14 & 18 & 30 & 37 \\ \text { Above a bachelor's } & 15 & 24 & 23 & 25\end{array}$

MSA

1970

$1980 \quad 1990$

2000

\section{Midwest}

St. Louis

$\begin{array}{lllll}\text { Less than high school } & 37 & 18 & 11 & 8\end{array}$

$\begin{array}{lllll}\text { HSD/GED } & 35 & 35 & 27 & 25\end{array}$

Some college, no degree $10 \quad 19 \quad 30 \quad 32$

$\begin{array}{lllll}\text { Bachelor's degree } & 10 & 14 & 21 & 23\end{array}$

$\begin{array}{lllll}\text { Above a bachelor's } & 8 & 14 & 11 & 12\end{array}$

Cleveland

$\begin{array}{lllll}\text { Less than high school } & 32 & 18 & 11 & 8\end{array}$

$\begin{array}{lllll}\text { HSD/GED } & 36 & 37 & 30 & 30\end{array}$

Some college, no degree $13 \quad 18 \quad 28 \quad 31$

$\begin{array}{lllll}\text { Bachelor's degree } & 10 & 15 & 19 & 21\end{array}$

$\begin{array}{lllll}\text { Above a bachelor's } & 8 & 13 & 11 & 11\end{array}$

Chicago

$\begin{array}{lllll}\text { Less than high school } & 30 & 15 & 9 & 6\end{array}$

$\begin{array}{lllll}\text { HSD/GED } & 33 & 32 & 22 & 20\end{array}$

Some college, no degree $\begin{array}{llll}16 & 20 & 29 & 29\end{array}$

$\begin{array}{lllll}\text { Bachelor's degree } & 12 & 17 & 25 & 29\end{array}$

$\begin{array}{lllll}\text { Above a bachelor's } & 10 & 16 & 15 & 17\end{array}$

Detroit

$\begin{array}{lllll}\text { Less than high school } & 35 & 19 & 12 & 9\end{array}$

$\begin{array}{lllll}\text { HSD/GED } & 34 & 35 & 27 & 26\end{array}$

Some college, no degree $13 \quad 21 \quad 34 \quad 34$

$\begin{array}{lllll}\text { Bachelor's degree } & 9 & 12 & 17 & 20\end{array}$

$\begin{array}{lllll}\text { Above a bachelor's } & 9 & 13 & 9 & 11\end{array}$

East

New York

$\begin{array}{lllll}\text { Less than high school } & 32 & 17 & 10 & 7\end{array}$

$\begin{array}{lllll}\text { HSD/GED } & 32 & 28 & 20 & 18\end{array}$

$\begin{array}{llll}\text { Some college, no degree } 12 & 17 & 22 & 22\end{array}$

$\begin{array}{lllll}\text { Bachelor's degree } & 11 & 17 & 25 & 30\end{array}$

$\begin{array}{lllll}\text { Above a bachelor's } & 13 & 22 & 22 & 24\end{array}$

Philadelphia

$\begin{array}{lllll}\text { Less than high school } & 34 & 19 & 10 & 7\end{array}$

$\begin{array}{lllll}\text { HSD/GED } & 36 & 37 & 31 & 29\end{array}$

Some college, no degree $11 \quad 15 \quad 23 \quad 25$

$\begin{array}{lllll}\text { Bachelor's degree } & 11 & 15 & 22 & 25\end{array}$

$\begin{array}{lllll}\text { Above a bachelor's } & 9 & 15 & 13 & 15\end{array}$

Baltimore

$\begin{array}{lllll}\text { Less than high school } & 41 & 23 & 12 & 9\end{array}$

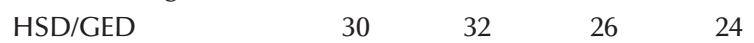

Some college, no degree $11 \quad 16 \quad 26 \quad 28$

$\begin{array}{lllll}\text { Bachelor's degree } & 10 & 14 & 21 & 24\end{array}$

$\begin{array}{lllll}\text { Above a bachelor's } & 8 & 15 & 14 & 16\end{array}$

NOTE: Authors' calculations. See Appendix 1 for details. HSD/GED, high school diploma or GED. 
Figure 3

Educational Attainment of Black and White Men: 1970-2000
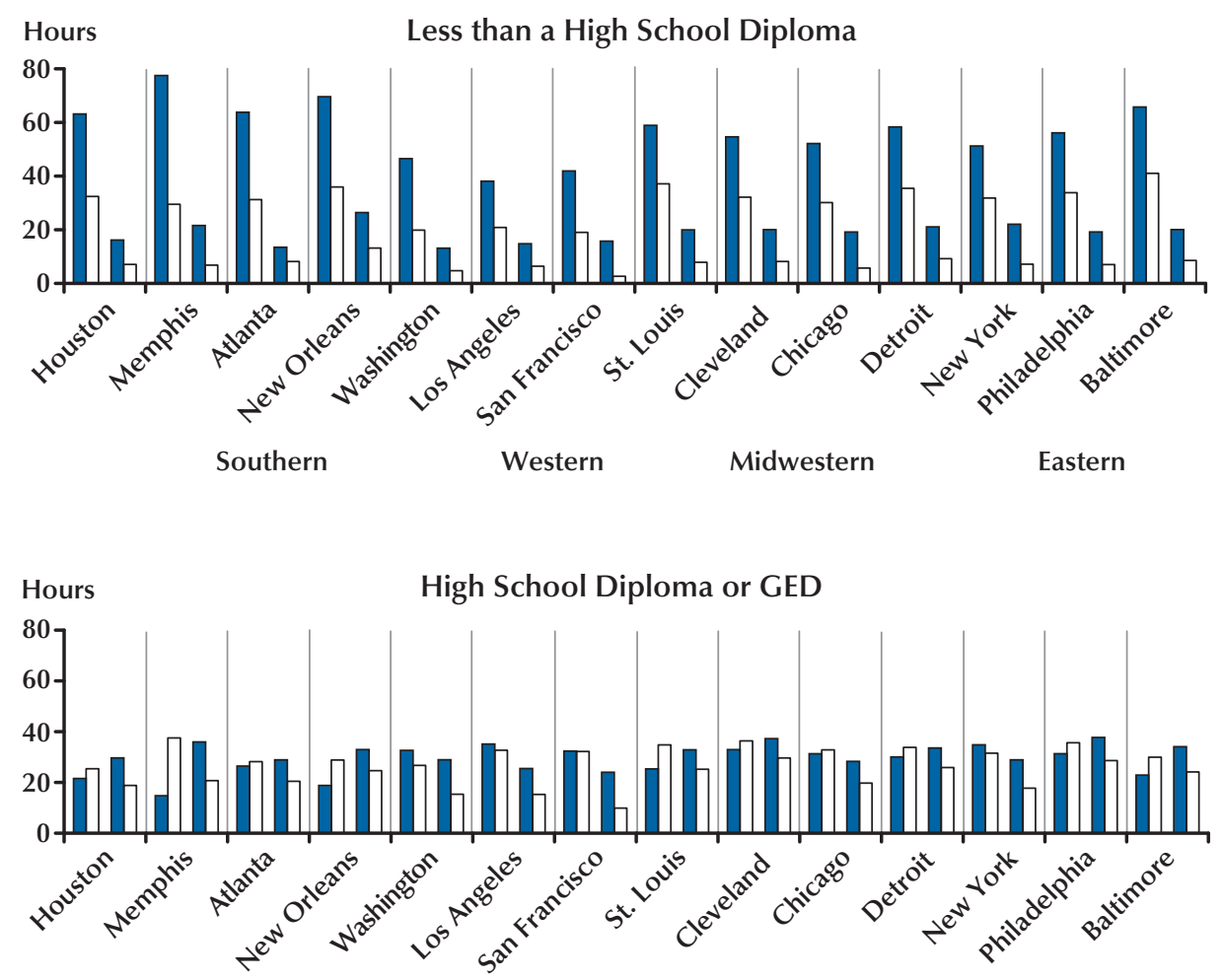

Southern Western Midwestern $\quad$ Eastern

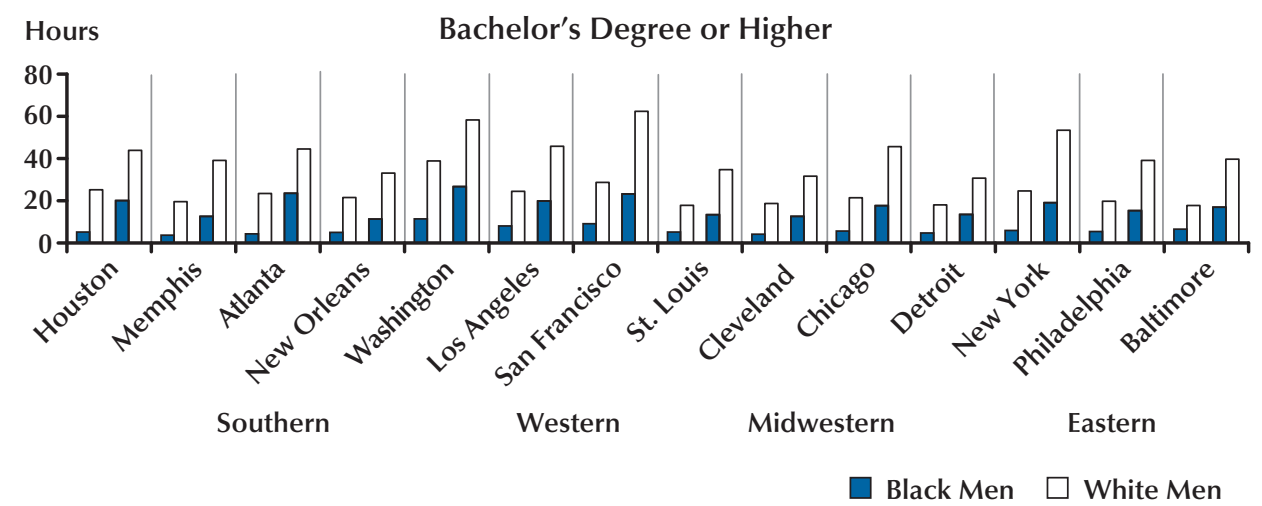




\section{Figure 4}

Marital Status of Black Men: 1970-2000
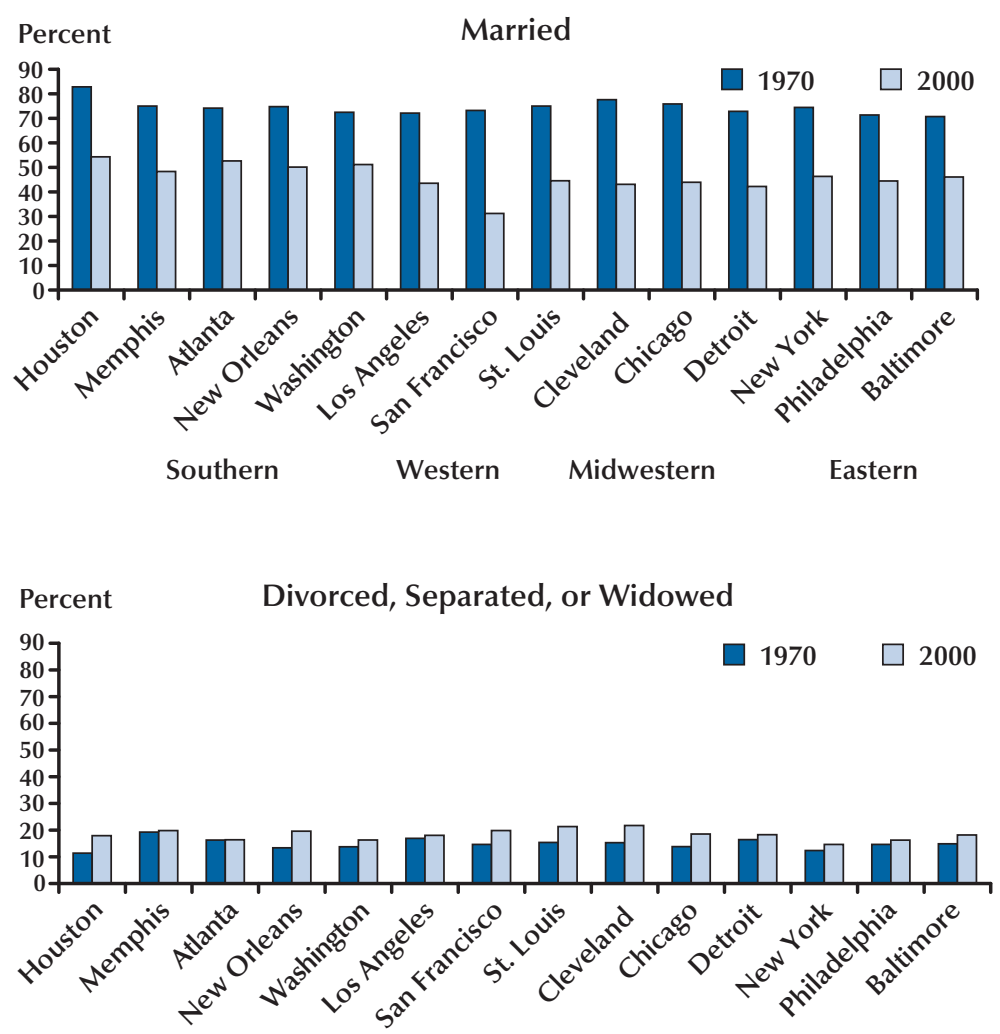

Southern Western Midwestern Eastern

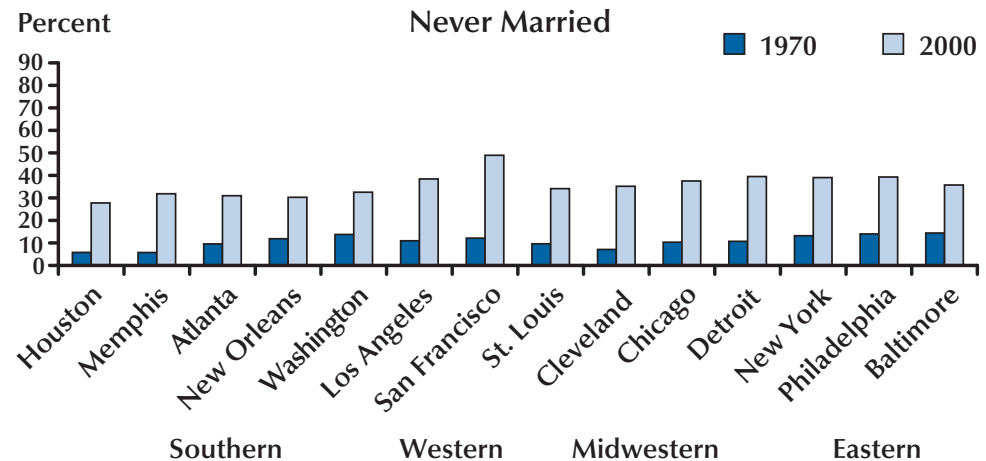


Table 8

Employment Distribution of All Men by Industry (percent)

\begin{tabular}{|c|c|c|c|c|c|c|c|c|c|}
\hline MSA & 1970 & 1980 & 1990 & 2000 & MSA & 1970 & 1980 & 1990 & 2000 \\
\hline $\begin{array}{l}\text { South } \\
\text { Houston }\end{array}$ & & & & & $\begin{array}{l}\text { Midwest } \\
\text { St. Louis }\end{array}$ & & & & \\
\hline Construction & 14 & 15 & 13 & 14 & Construction & 8 & 8 & 10 & 11 \\
\hline Manufacturing & 28 & 24 & 18 & 16 & Manufacturing & 37 & 32 & 26 & 20 \\
\hline Transportation & 11 & 10 & 10 & 10 & Transportation & 12 & 12 & 11 & 11 \\
\hline Sales & 18 & 17 & 20 & 18 & Sales & 16 & 15 & 17 & 16 \\
\hline Finance & 3 & 4 & 5 & 4 & Finance & 3 & 4 & 5 & 5 \\
\hline Service & 16 & 18 & 22 & 24 & Service & 13 & 17 & 20 & 25 \\
\hline Public administration & 3 & 3 & 3 & 3 & Public administration & 6 & 6 & 5 & 4 \\
\hline Other & 7 & 9 & 9 & 10 & Other & 5 & 6 & 6 & 7 \\
\hline Memphis & & & & & Cleveland & & & & \\
\hline Construction & 7 & 8 & 9 & 9 & Construction & 8 & 8 & 8 & 10 \\
\hline Manufacturing & 25 & 22 & 16 & 13 & Manufacturing & 45 & 39 & 28 & 26 \\
\hline Transportation & 13 & 14 & 14 & 17 & Transportation & 10 & 10 & 10 & 8 \\
\hline Sales & 20 & 19 & 20 & 18 & Sales & 15 & 14 & 17 & 15 \\
\hline Finance & 4 & 5 & 5 & 4 & Finance & 4 & 4 & 5 & 5 \\
\hline Service & 17 & 18 & 22 & 24 & Service & 13 & 17 & 21 & 23 \\
\hline Public administration & 6 & 6 & 6 & 5 & Public administration & 4 & 4 & 4 & 5 \\
\hline Other & 8 & 7 & 9 & 9 & Other & 2 & 4 & 7 & 7 \\
\hline Atlanta & & & & & Chicago & & & & \\
\hline Construction & 10 & 9 & 11 & 12 & Construction & 8 & 8 & 8 & 10 \\
\hline Manufacturing & 26 & 20 & 15 & 14 & Manufacturing & 37 & 31 & 23 & 20 \\
\hline Transportation & 12 & 14 & 13 & 13 & Transportation & 12 & 12 & 11 & 11 \\
\hline Sales & 21 & 20 & 22 & 19 & Sales & 17 & 16 & 18 & 16 \\
\hline Finance & 6 & 6 & 7 & 6 & Finance & 4 & 6 & 7 & 7 \\
\hline Service & 16 & 20 & 23 & 25 & Service & 15 & 19 & 23 & 26 \\
\hline Public administration & 5 & 6 & 5 & 4 & Public administration & 4 & 5 & 4 & 4 \\
\hline Other & 4 & 5 & 4 & 6 & Other & 3 & 5 & 6 & 7 \\
\hline New Orleans & & & & & Detroit & & & & \\
\hline Construction & 11 & 12 & 9 & 12 & Construction & 7 & 6 & 8 & 9 \\
\hline Manufacturing & 20 & 14 & 12 & 12 & Manufacturing & 51 & 45 & 35 & 33 \\
\hline Transportation & 16 & 15 & 12 & 11 & Transportation & 8 & 8 & 7 & 8 \\
\hline Sales & 18 & 18 & 19 & 17 & Sales & 13 & 13 & 16 & 15 \\
\hline Finance & 6 & 4 & 4 & 4 & Finance & 3 & 3 & 4 & 4 \\
\hline Service & 17 & 20 & 25 & 26 & Service & 13 & 15 & 19 & 21 \\
\hline Public administration & 5 & 6 & 5 & 5 & Public administration & 4 & 4 & 3 & 3 \\
\hline Other & 7 & 11 & 14 & 14 & Other & 2 & 4 & 6 & 7 \\
\hline Washington, D.C. & & & & & East & & & & \\
\hline Construction & 8 & 8 & 11 & 11 & New York & & & & \\
\hline Manufacturing & 7 & 6 & 7 & 6 & Construction & 6 & 5 & 7 & 8 \\
\hline Transportation & 9 & 9 & 9 & 10 & Manufacturing & 20 & 17 & 11 & 8 \\
\hline Sales & 13 & 12 & 14 & 13 & Transportation & 16 & 13 & 12 & 12 \\
\hline Finance & 4 & 5 & 6 & 5 & Sales & 19 & 17 & 17 & 16 \\
\hline Service & 21 & 26 & 29 & 34 & Finance & 8 & 9 & 11 & 10 \\
\hline Public administration & 26 & 24 & 16 & 13 & Service & 22 & 26 & 29 & 31 \\
\hline Other & 12 & 9 & 8 & 8 & Public administration & 5 & 6 & 5 & 5 \\
\hline West & & & & & Other & 4 & 7 & 9 & 11 \\
\hline Los Angeles & & & & & Philadelphia & & & & \\
\hline Construction & 7 & 7 & 9 & 9 & Construction & 8 & 8 & 10 & 10 \\
\hline Manufacturing & 33 & 29 & 23 & 17 & Manufacturing & 36 & 28 & 21 & 16 \\
\hline Transportation & 10 & 9 & 8 & 9 & Transportation & 10 & 10 & 9 & 10 \\
\hline Sales & 17 & 17 & 18 & 19 & Sales & 16 & 16 & 18 & 17 \\
\hline Finance & 4 & 5 & 6 & 5 & Finance & 4 & 5 & 6 & 6 \\
\hline Service & 20 & 23 & 25 & 30 & Service & 15 & 20 & 23 & 28 \\
\hline Public administration & 4 & 4 & 3 & 3 & Public administration & 6 & 6 & 5 & 5 \\
\hline Other & 4 & 6 & 7 & 9 & Other & 5 & 6 & 7 & 8 \\
\hline San Francisco & & & & & Baltimore & & & & \\
\hline Construction & 9 & 8 & 8 & 8 & Construction & 9 & 10 & 12 & 11 \\
\hline Manufacturing & 20 & 17 & 11 & 10 & Manufacturing & 31 & 22 & 16 & 12 \\
\hline Transportation & 14 & 12 & 11 & 9 & Transportation & 11 & 11 & 10 & 10 \\
\hline Sales & 18 & 18 & 19 & 18 & Sales & 14 & 14 & 16 & 16 \\
\hline Finance & 6 & 7 & 8 & 8 & Finance & 4 & 4 & 5 & 6 \\
\hline Service & 21 & 25 & 30 & 38 & Service & 15 & 18 & 22 & 28 \\
\hline Public administration & 7 & 6 & 4 & 3 & Public administration & 9 & 13 & 11 & 9 \\
\hline Other & 5 & 6 & 7 & 6 & Other & 7 & 8 & 8 & 8 \\
\hline
\end{tabular}

NOTE: Authors' calculations. See Appendix 1 for details. 


\section{Table 9}

\section{Employment Distribution of Black Men by Industry (percent)}

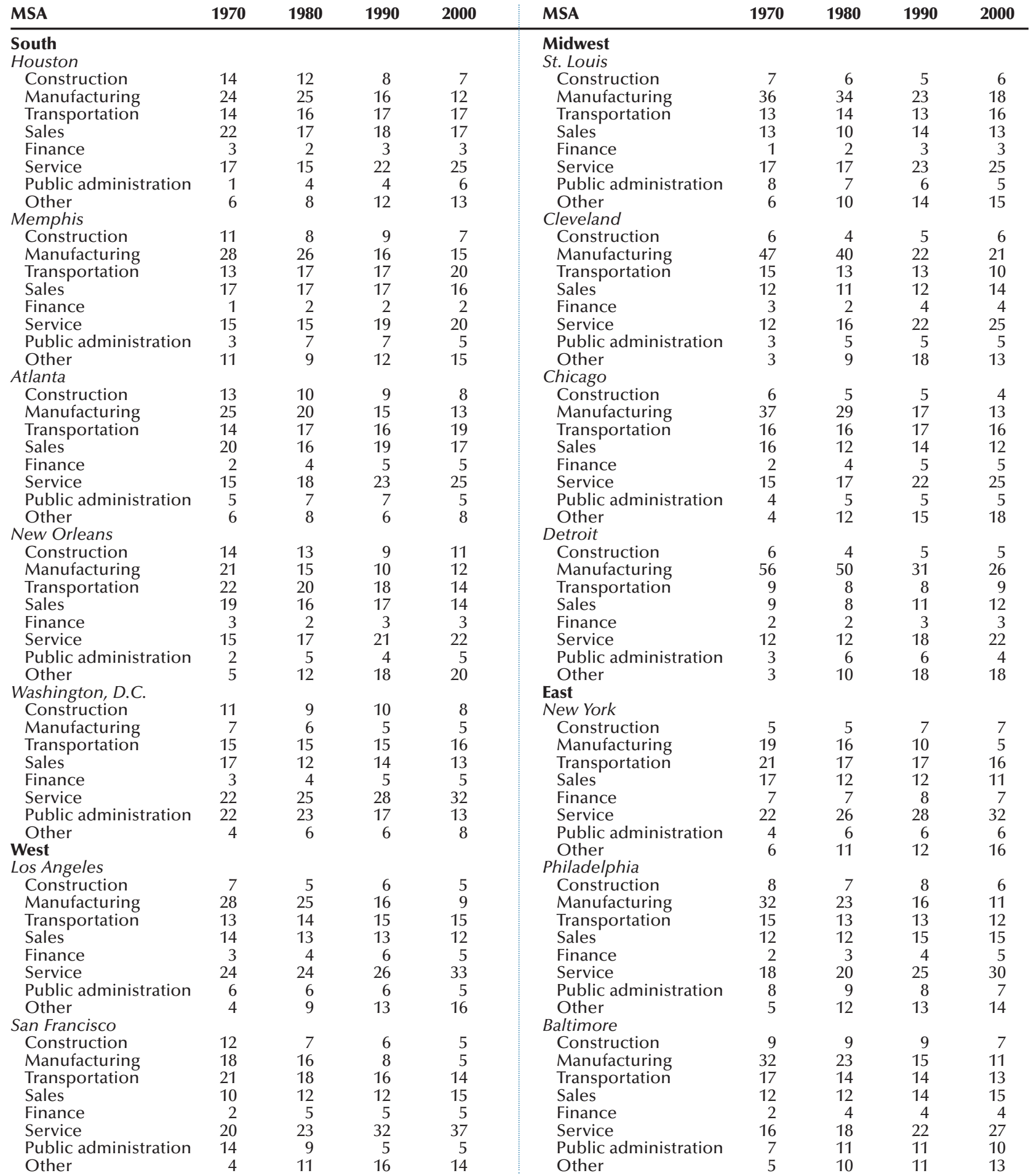

NOTE: Authors' calculations. See Appendix 1 for details. 
Table 10

\section{Overall Population Changes by MSA (percent)}

MSA

$1970-80 \quad 1980-90 \quad 1990-2000$

South

Houston

Memphis

Atlanta

New Orleans

Washington, D.C.

\section{East}

New York

Philadelphia

Baltimore

Midwest

St. Louis

Cleveland

Chicago

Detroit

West

Los Angeles

San Francisco

United States

27

\section{5}

10

27

14

9

21

$-9 \quad 3$

$\begin{array}{ll}-2 & 3\end{array}$

5

8

$\begin{array}{rr}-2 & 3 \\ -6 & -3 \\ 2 & 2 \\ -2 & -3\end{array}$

SOURCE: Metropolitan (MSA) Population Data: Population and Household Data, U.S. Metropolitan Statistical Areas, MSA (1999 definition), 1970-present, Real Estate Center, Texas A\&M University; http://recenter.tamu.edu/data/popm/.

populations as well. ${ }^{21}$ Thus, while manufacturing was losing its importance and labor market conditions were deteriorating, black population in those cities was increasing.

On the other hand, rapidly growing cities, such as Houston and Atlanta, had large increases in black population as well. What sets Atlanta apart, however, is that black population there was growing even faster than the overall city population.

Tables 12 and 13 report changes in the population of black and white men, respectively, by

\footnotetext{
${ }^{21}$ It is tempting to explain these changes by recalling that one of the main demographic trends during the 1970 s and 1980s was the migration of white population away from urban centers. Readers are reminded, however, that the unit of analysis in this paper is a metropolitan area that includes a central city together with adjacent communities (usually counties). Thus, the observed phenomenon cannot be explained only by white flight to the suburbs.
}

\section{Table 11}

Black Population Changes by MSA (percent)

MSA

1970-80

$1980-90$

1990-2000

South

Houston

Memphis

Atlanta

New Orleans

37

37
16

$\begin{array}{rr}18 & 22 \\ 9 & 14 \\ 39 & 33 \\ 5 & 2 \\ 20 & 11\end{array}$

East

New York
Philadelphia
Baltimore

Midwest

St. Louis
Cleveland
Chicago
Detroit

West

Los Angeles
San Francisco
United States

41

19

15

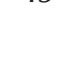

$\begin{array}{rrr}13 & 22 & 3 \\ 5 & 6 & 4 \\ 13 & 10 & 13\end{array}$

$\begin{array}{rrr}13 & 22 & 3 \\ 5 & 6 & 4 \\ 13 & 10 & 13\end{array}$

$\begin{array}{rll}7 & 4 & 7 \\ 5 & 3 & 8 \\ 17 & 0 & 7 \\ 16 & 6 & 7\end{array}$

United States

24
1
17

$\begin{array}{rr}9 & 1 \\ -4 & 2 \\ 13 & 16\end{array}$

SOURCE: Population Estimates Archives, U.S. Census Bureau.

decades: 1970-80, 1980-90, and 1990-2000. As expected, changes in the population of black men (Table 12) are consistent with changes in black population in general (see Table 11). However, they vary widely with the changes in the population of white men. While the population of black men was increasing in the three decades in almost all cities, the population of white men was decreasing. For example, in New York in 1980-90, the population of black men grew by 23 percent while the population of white men decreased by 31 percent. Other eastern and midwestern cities had a similar experience. Even when the population of white men grew, it did so at a lower rate than the population of black men. The $1970-80$ population increase in Los Angeles was 1 percent for white men and 24 percent for black men.

Table 14 offers a different way to look at migration flows of blacks. It reports the proportion of black men who were "locals" in the 14 


\section{Table 12}

\section{Black Male Population Changes by MSA (percent)}

\begin{tabular}{lrrr} 
MSA & $\mathbf{1 9 7 0 - 8 0}$ & $\mathbf{1 9 8 0 - 9 0}$ & $\mathbf{1 9 9 0 - 2 0 0 0}$ \\
\hline South & 37 & 18 & 21 \\
Houston & 15 & 8 & 14 \\
Memphis & 41 & 41 & 33 \\
Atlanta & 18 & 3 & 2 \\
New Orleans & 13 & 19 & 11 \\
Washington, D.C. & & & \\
East & & & \\
New York & 11 & 23 & 4 \\
Philadelphia & 4 & 6 & 4 \\
$\quad$ Baltimore & 11 & 10 & 12 \\
Midwest & & & \\
St. Louis & 6 & 3 & 7 \\
Cleveland & 3 & 2 & 9 \\
Chicago & 15 & 0 & 7 \\
$\quad$ Detroit & 14 & 4 & 7 \\
West & & & \\
Los Angeles & 24 & 9 & 0 \\
San Francisco & 2 & -2 & 2
\end{tabular}

SOURCE: Population Estimates Archives, U.S. Census Bureau.

cities, meaning those born in the relevant state or, for some cities, born in a specified neighboring state. Ideally, we would like to know how many men were born in the city they lived in, but the data do not offer this information. In 1970, the southern cities had a very high proportion of black men who were locals. In 1970, for example, in Memphis, 91 percent of black men were locals born either in Tennessee or Mississippi; in Atlanta, 86 percent were locals and born in Georgia. The difference between these two cities, however, is that while the black population of Memphis stayed predominantly local throughout the three decades, Atlanta had a steady inflow of migrants from other parts of the country. In Atlanta, by 1980 the proportion of locals declined to 73 percent, by 1990 to 55 percent, and by 2000 to only 43 percent. This "churning" of the population contributed to Atlanta having one of the highest

\section{Table 13}

\section{White Male Population Changes by MSA (percent)}

\begin{tabular}{lrrr} 
MSA & $\mathbf{1 9 7 0 - 8 0}$ & $\mathbf{1 9 8 0 - 9 0}$ & $\mathbf{1 9 9 0 - 2 0 0 0}$ \\
\hline South & & & \\
Houston & 48 & -15 & 9 \\
Memphis & 4 & 5 & 5 \\
Atlanta & 22 & 26 & 24 \\
New Orleans & 11 & -12 & -1 \\
Washington, D.C. & -1 & 11 & 6 \\
East & & & \\
New York & -17 & -31 & -9 \\
Philadelphia & -5 & -3 & -3 \\
Baltimore & 1 & 5 & 0 \\
Midwest & & & \\
St. Louis & -4 & 2 & 2 \\
Cleveland & -8 & -8 & -2 \\
Chicago & -3 & -14 & 2 \\
Detroit & -8 & -8 & 3 \\
West & & & -14 \\
Los Angeles & 1 & -40 & -9 \\
San Francisco & -6 & -18 &
\end{tabular}

SOURCE: Population Estimates Archives, U.S. Census Bureau.

average educational attainments of black men. Recall also that in 2000 black men in Atlanta had the highest employment rate and lowest unemployment rate.

Table 14 shows that in the midwestern cities the population dynamic was the opposite of that in Atlanta. In 1970, most black men living in these cities were born elsewhere. This was, of course, a result of the Great Migration in the earlier part of the century that moved blacks northward. In 1970, only 28 percent of black men in Detroit were born in Michigan; in Cleveland, Chicago, and St. Louis the proportions of locals were, respectively, 34, 36, and 37 percent. In the following three decades, however, the inflow significantly decreased: By 2000, the proportion of black men in Detroit who were born in Michigan reached 69 percent. The other midwestern cities experienced similar increases. 
Table 14

\begin{tabular}{|c|c|c|c|c|}
\hline MSA & 1970 & 1980 & 1990 & 2000 \\
\hline \multicolumn{5}{|l|}{ South } \\
\hline Live in Houston, born in TX & 74 & 65 & 61 & 61 \\
\hline Live in Memphis, born in TN or MS & 91 & 91 & 88 & 84 \\
\hline Live in Atlanta, born in GA & 86 & 73 & 55 & 43 \\
\hline Live in New Orleans, born in LA & 82 & 81 & 84 & 86 \\
\hline Live in $\mathrm{DC}$, born in $\mathrm{MD}$, $\mathrm{VA}$, or $\mathrm{DC}$ & 56 & 50 & 52 & 52 \\
\hline \multicolumn{5}{|l|}{ East } \\
\hline Live in New York, born in NY & 38 & 30 & 35 & 40 \\
\hline Live in Philadelphia, born in PA or NJ & 54 & 59 & 69 & 73 \\
\hline Live in Baltimore, born in MD & 54 & 58 & 65 & 66 \\
\hline \multicolumn{5}{|l|}{ Midwest } \\
\hline Live in St. Louis, born in $\mathrm{MO}$ & 37 & 44 & 58 & 64 \\
\hline Live in Cleveland, born in $\mathrm{OH}$ & 34 & 41 & 57 & 72 \\
\hline Live in Chicago, born in IL & 36 & 38 & 56 & 67 \\
\hline Live in Detroit, born in MI & 28 & 39 & 58 & 69 \\
\hline \multicolumn{5}{|l|}{ West } \\
\hline Live in Los Angeles, born in CA & 13 & 21 & 34 & 47 \\
\hline Live in San Francisco, born in CA & 15 & 25 & 37 & 45 \\
\hline
\end{tabular}

The picture of migration is somewhat similar, though less dramatic, in Philadelphia and Baltimore. In New York, the proportion of locals stayed pretty stable in the 30 to 40 percent range. In 1970 in the western cities, San Francisco and Los Angeles, only a small proportion of black men were locals (15 and 13 percent, respectively). By 2000 , the proportions increased to 45 percent in San Francisco and 47 percent in Los Angeles.

Differences in migration are clearly related to differences in the economic well-being of black men across cities. Cities that are doing well, such as Atlanta, attract more educated workers looking for good job opportunities. Struggling cities have difficulty raising their levels of human capital because they cannot attract talented, educated workers from other places and are losing their own educated population.

\section{CHANGES IN FAMILY STRUCTURE}

Stable families are important indicators of healthy communities. Table 15 shows the distribution of the marital status of black men in each city in 1970, 1980, 1990, and 2000 in these categories: married, divorced/separated/widowed, and never married. Figure 4 compares changes in these distributions between 1970 and 2000. The most striking finding is that marriage rates of black men decreased dramatically between 1970 and 2000 .

In 1970 across the cities, the rates varied from 71 percent (in Baltimore and Philadelphia) to 83 percent (in Houston). By 2000, the rates varied from only 31 to 54 percent $^{22}$ and were

22 Table 16 presents the statistics for white men based on the same categories and shows their marriage rates declined as well but not as dramatically. In 1970, 78 to 89 percent of white men were married. By 2000, the proportion had declined to 47 to 69 percent. 


\section{Table 15}

\section{Marital Status of Black Men by MSA (percent)}

\begin{tabular}{|c|c|c|c|c|c|c|c|c|c|}
\hline MSA & 1970 & 1980 & 1990 & 2000 & MSA & 1970 & 1980 & 1990 & 2000 \\
\hline South & & & & & Midwest & & & & \\
\hline Houston & & & & & St. Louis & & & & \\
\hline Married & 83 & 67 & 54 & 54 & Married & 75 & 59 & 47 & 45 \\
\hline $\mathrm{D} / \mathrm{S} / \mathrm{W}$ & 11 & 17 & 21 & 18 & $\mathrm{D} / \mathrm{S} / \mathrm{W}$ & 15 & 23 & 20 & 21 \\
\hline Never married & 6 & 16 & 26 & 28 & Never married & 10 & 18 & 33 & 34 \\
\hline Memphis & & & & & Cleveland & & & & \\
\hline Married & 75 & 58 & 49 & 48 & Married & 78 & 60 & 47 & 43 \\
\hline $\mathrm{D} / \mathrm{S} / \mathrm{W}$ & 19 & 22 & 21 & 20 & $\mathrm{D} / \mathrm{S} / \mathrm{W}$ & 15 & 21 & 25 & 22 \\
\hline Never married & 6 & 20 & 30 & 32 & Never married & 7 & 19 & 28 & 35 \\
\hline Atlanta & & & & & Chicago & & & & \\
\hline Married & 74 & 61 & 53 & 53 & Married & 76 & 57 & 44 & 44 \\
\hline $\mathrm{D} / \mathrm{S} / \mathrm{W}$ & 16 & 19 & 18 & 16 & $\mathrm{D} / \mathrm{S} / \mathrm{W}$ & 14 & 21 & 21 & 19 \\
\hline Never married & 10 & 20 & 29 & 31 & Never married & 10 & 21 & 36 & 38 \\
\hline New Orleans & & & & & Detroit & & & & \\
\hline Married & 75 & 61 & 50 & 50 & Married & 73 & 55 & 43 & 42 \\
\hline $\mathrm{D} / \mathrm{S} / \mathrm{W}$ & 13 & 20 & 20 & 20 & $\mathrm{D} / \mathrm{S} / \mathrm{W}$ & 16 & 24 & 23 & 18 \\
\hline Never married & 12 & 18 & 30 & 30 & Never married & 11 & 21 & 34 & 39 \\
\hline Washington, D.C. & & & & & East & & & & \\
\hline Married & 72 & 56 & 49 & 51 & New York & & & & \\
\hline $\mathrm{D} / \mathrm{S} / \mathrm{W}$ & 14 & 22 & 17 & 16 & Married & 74 & 57 & 49 & 46 \\
\hline Never married & 14 & 23 & 34 & 33 & $\mathrm{D} / \mathrm{S} / \mathrm{W}$ & 12 & 19 & 17 & 15 \\
\hline West & & & & & Never married & 13 & 24 & 35 & 39 \\
\hline Los Angeles & & & & & Philadelphia & & & & \\
\hline Married & 72 & 55 & 46 & 44 & Married & 71 & 54 & 45 & 44 \\
\hline $\mathrm{D} / \mathrm{S} / \mathrm{W}$ & 17 & 23 & 21 & 18 & $\mathrm{D} / \mathrm{S} / \mathrm{W}$ & 15 & 23 & 20 & 16 \\
\hline Never married & 11 & 22 & 34 & 38 & Never married & 14 & 23 & 35 & 39 \\
\hline San Francisco & & & & & Baltimore & & & & \\
\hline Married & 73 & 51 & 39 & 31 & Married & 71 & 52 & 44 & 46 \\
\hline $\mathrm{D} / \mathrm{S} / \mathrm{W}$ & 15 & 23 & 21 & 20 & $\mathrm{D} / \mathrm{S} / \mathrm{W}$ & 15 & 24 & 20 & 18 \\
\hline Never married & 12 & 26 & 40 & 49 & Never married & 14 & 24 & 36 & 36 \\
\hline
\end{tabular}

NOTE: Authors' calculations. See Appendix 1 for details. D/S/W, divorced/separated/widowed. 
Table 16

Marital Status of White Men by MSA (percent)

\begin{tabular}{|c|c|c|c|c|c|c|c|c|c|}
\hline MSA & 1970 & 1980 & 1990 & 2000 & MSA & 1970 & 1980 & 1990 & 2000 \\
\hline South & & & & & Midwest & & & & \\
\hline Houston & & & & & St. Louis & & & & \\
\hline Married & 88 & 76 & 70 & 69 & Married & 88 & 81 & 72 & 69 \\
\hline $\mathrm{D} / \mathrm{S} / \mathrm{W}$ & 6 & 12 & 13 & 14 & $\mathrm{D} / \mathrm{S} / \mathrm{W}$ & 5 & 9 & 11 & 13 \\
\hline Never married & 6 & 12 & 17 & 17 & Never married & 7 & 11 & 17 & 18 \\
\hline Memphis & & & & & Cleveland & & & & \\
\hline Married & 89 & 79 & 72 & 69 & Married & 86 & 77 & 69 & 66 \\
\hline $\mathrm{D} / \mathrm{S} / \mathrm{W}$ & 4 & 11 & 11 & 15 & $\mathrm{D} / \mathrm{S} / \mathrm{W}$ & 5 & 8 & 11 & 13 \\
\hline Never married & 7 & 11 & 16 & 16 & Never married & 9 & 14 & 20 & 21 \\
\hline Atlanta & & & & & Chicago & & & & \\
\hline Married & 88 & 77 & 71 & 69 & Married & 84 & 75 & 66 & 67 \\
\hline D/S/W & 5 & 11 & 11 & 12 & D/S/W & 5 & 9 & 10 & 10 \\
\hline Never married & 7 & 12 & 18 & 19 & Never married & 11 & 16 & 24 & 23 \\
\hline New Orleans & & & & & Detroit & & & & \\
\hline Married & 85 & 74 & 66 & 63 & Married & 87 & 78 & 71 & 67 \\
\hline $\mathrm{D} / \mathrm{S} / \mathrm{W}$ & 6 & 11 & 13 & 14 & $\mathrm{D} / \mathrm{S} / \mathrm{W}$ & 5 & 10 & 11 & 12 \\
\hline Never married & 10 & 15 & 21 & 22 & Never married & 9 & 13 & 18 & 21 \\
\hline Washington, D.C. & & & & & East & & & & \\
\hline Married & 85 & 71 & 65 & 66 & New York & & & & \\
\hline $\mathrm{D} / \mathrm{S} / \mathrm{W}$ & 5 & 11 & 10 & 11 & Married & 78 & 67 & 59 & 58 \\
\hline Never married & 10 & 19 & 24 & 23 & D/S/W & 5 & 9 & 9 & 9 \\
\hline West & & & & & Never married & 17 & 25 & 33 & 34 \\
\hline Los Angeles & & & & & Philadelphia & & & & \\
\hline Married & 79 & 63 & 56 & 54 & Married & 85 & 76 & 70 & 68 \\
\hline D/S/W & 9 & 15 & 14 & 13 & $\mathrm{D} / \mathrm{S} / \mathrm{W}$ & 5 & 9 & 9 & 10 \\
\hline Never married & 12 & 22 & 30 & 33 & Never married & 10 & 15 & 21 & 22 \\
\hline San Francisco & & & & & Baltimore & & & & \\
\hline Married & 79 & 62 & 50 & 47 & Married & 86 & 76 & 70 & 67 \\
\hline $\mathrm{D} / \mathrm{S} / \mathrm{W}$ & 8 & 14 & 13 & 11 & $\mathrm{D} / \mathrm{S} / \mathrm{W}$ & 6 & 11 & 12 & 13 \\
\hline Never married & 14 & 24 & 37 & 42 & Never married & 8 & 14 & 19 & 20 \\
\hline
\end{tabular}

NOTE: Authors' calculations. See Appendix 1 for details. D/S/W, divorced/separated/widowed. 
particularly low in the western and midwestern cities: Only 31 percent of black men were married in San Francisco, 44 percent in Los Angeles, and only 42 to 45 percent in the midwestern cities overall. Houston still had the highest proportion of married black men in 2000, but it was down to 54 percent. Atlanta had the second highest53 percent. Overall, as shown in Table 15, the largest decline in marriage rates occurred between 1970 and 1980, followed by a somewhat smaller decline between 1980 and 1990. The rates then stayed essentially the same between 1990 and 2000.

Remarkably, as easily seen in Figure 4, divorce rates for black men from 1970 to 2000 did not change much in most cities. Instead, the proportion who have never married increased dramatically-in some cities by more than five times. In 1970 in Memphis, for instance, only 6 percent of black men had never married and in San Francisco only 12 percent (see Table 15). In 2000, the proportion reached 32 percent in Memphis and 49 percent in San Francisco. In midwestern cities, the proportion increased from 7 to 11 percent in 1970 to 34 to 39 percent in 2000.

This trend describes significant demographic changes in the black community. ${ }^{23}$ One direct consequence is more single mothers and, thus, more children who grow up in single-parent households.

\section{THE WELL-BEING OF BLACK CHILDREN}

The paper thus far has documented mainly negative developments in economic and social conditions of blacks between 1970 and 2000: increased rates of unemployment and those not

\footnotetext{
${ }^{23}$ There is a literature that suggests that the structure of welfare payments discourages marriage (e.g., Duncan and Hoffman, 1990, and Lichter, LeClere, and McLaughlin, 1991). Moffit (1997), however, reviews this literature and concludes that "considerable uncertainty surrounds this consensus because a significant minority of the studies find no effect at all, because the magnitudes of the estimated effects vary widely, and because puzzling and unexplained differences exist across the studies by race and methodological approach” (p. 1). Black, McKinnish, and Sanders (2003) find that when low-skilled workers have high-wage jobs (as did miners during the coal boom), welfare expenditure decreases partly because of the decline in single-parent households.
}

in the labor force, decreased relative annual incomes, insufficient progress in educational attainment, and decreased marriage rates. One question that seems very important is how these changes affect the well-being of the children. Has there been any progress in their welfare? To address this question in the most straightforward way, we compare the income distributions of white and black families with children 8 to 12 years old.$^{24}$ Comparison of family incomes allows us to summarize how decreased marriage rates, increased single-mother households, and changes in labor force participation and wages affect children; it also allows us to capture the economic progress of women. ${ }^{25}$

First we compute an annual income distribution of white children's families. Then we calculate the 75th percentile, the median, and the 25th percentile of annual income distribution of black children's families. Finally, we determine where each of these quartiles of black family income distribution falls in the white family income distribution. The results are reported in Table 17.

Consider Houston in 1970, for instance. As the table shows, the median family income of black children corresponds to the 12th percentile of white children, which means that only 12 percent of white children had family income below the median family income of black children. Put another way, half of black children have family income that was less than that of 88 percent of white children.

Charles and Luoh (forthcoming) present evidence that an increase in incarceration rates of black men negatively affected the marriage market for black women. It led to a shift of gains from marriage from women toward men. Our sample, however, does not include men in prison at the time of the survey. Thus, the estimated marriage rates are likely to be even lower if one includes incarcerated men.

${ }^{24}$ For this exercise, the income measurement we use includes annual pre-tax family income from all sources, including Social Security and welfare payments, as well as veterans' payments, unemployment compensation, child support, and alimony. Incomes were recorded for all persons in a family who were 15 years old and older (14 years old and older in 1970 data).

${ }^{25}$ We do not study economic progress of black women in this paper, leaving this important topic to future research. Stagnation of the economic progress of black men is likely to have behavioral responses from women. Charles and Luoh (forthcoming) find, for example, that black women who face marriage markets with reduced quality of potential spouses increase their schooling and labor supply. 
Table 17

Well-Being of Black Children Compared with White Children Based on Place in Family Income Distribution of White Children (Percentile)

\begin{tabular}{|c|c|c|c|c|c|c|c|c|c|}
\hline MSA & 1970 & 1980 & 1990 & 2000 & MSA & 1970 & 1980 & 1990 & 2000 \\
\hline South & & & & & Midwest & & & & \\
\hline Houston & & & & & St. Louis & & & & \\
\hline 75th percentile & 27 & 38 & 39 & 38 & 75th percentile & 37 & 37 & 39 & 33 \\
\hline Median & 12 & 14 & 15 & 16 & Median & 12 & 12 & 13 & 12 \\
\hline 25th percentile & 4 & 4 & 4 & 6 & 25th percentile & 4 & 4 & 4 & 4 \\
\hline Ratio of medians & 0.5 & 0.5 & 0.5 & 0.4 & Ratio of medians & 0.5 & 0.4 & 0.4 & 0.4 \\
\hline Memphis & & & & & Cleveland & & & & \\
\hline 75th percentile & 20 & 34 & 32 & 33 & 75th percentile & 35 & 43 & 44 & 39 \\
\hline Median & 8 & 14 & 10 & 12 & Median & 10 & 12 & 15 & 14 \\
\hline 25th percentile & 4 & 5 & 3 & 3 & 25th percentile & 4 & 4 & 4 & 5 \\
\hline Ratio of medians & 0.4 & 0.4 & 0.4 & 0.4 & Ratio of medians & 0.5 & 0.5 & 0.5 & 0.4 \\
\hline Atlanta & & & & & Chicago & & & & \\
\hline 75th percentile & 27 & 32 & 39 & 40 & 75th percentile & 33 & 37 & 37 & 34 \\
\hline Median & 12 & 15 & 13 & 17 & Median & 11 & 11 & 11 & 11 \\
\hline 25th percentile & 6 & 3 & 10 & 7 & 25th percentile & 4 & 4 & 3 & 3 \\
\hline Ratio of medians & 0.5 & 0.5 & 0.5 & 0.5 & Ratio of medians & 0.6 & 0.4 & 0.4 & 0.4 \\
\hline New Orleans & & & & & Detroit & & & & \\
\hline 75th percentile & 26 & 35 & 32 & 35 & 75th percentile & 45 & 45 & 41 & 42 \\
\hline Median & 10 & 13 & 9 & 14 & Median & 14 & 18 & 14 & 16 \\
\hline 25th percentile & 4 & 4 & 3 & 4 & 25th Percentile & 4 & 7 & 5 & 6 \\
\hline Ratio of medians & 0.5 & 0.4 & 0.3 & 0.4 & Ratio of medians & 0.6 & 0.6 & 0.4 & 0.5 \\
\hline Washington, D.C. & & & & & East & & & & \\
\hline 75th percentile & 33 & 44 & 47 & 40 & New York & & & & \\
\hline Median & 13 & 17 & 17 & 17 & 75th percentile & 40 & 40 & 46 & 43 \\
\hline 25th percentile & 6 & 6 & 5 & 4 & Median & 15 & 16 & 21 & 23 \\
\hline Ratio of medians & 0.5 & 0.6 & 0.6 & 0.5 & 25th percentile & 6 & 6 & 7 & 7 \\
\hline West & & & & & Ratio of medians & 0.5 & 0.5 & 0.5 & 0.5 \\
\hline Los Angeles & & & & & Philadelphia & & & & \\
\hline 75th percentile & 36 & 44 & 51 & 39 & 75th percentile & 44 & 41 & 46 & 40 \\
\hline Median & 15 & 20 & 18 & 17 & Median & 14 & 15 & 14 & 13 \\
\hline 25th percentile & 6 & 8 & 7 & 6 & 25th percentile & 5 & 5 & 5 & 4 \\
\hline Ratio of medians & 0.5 & 0.5 & 0.5 & 0.4 & Ratio of medians & 0.6 & 0.5 & 0.5 & 0.5 \\
\hline San Francisco & & & & & Baltimore & & & & \\
\hline 75th percentile & 46 & 41 & 37 & 36 & 75th percentile & 46 & 41 & 43 & 41 \\
\hline Median & 16 & 17 & 17 & 11 & Median & 16 & 15 & 15 & 16 \\
\hline 25th percentile & 7 & 6 & 4 & 4 & 25th percentile & 6 & 3 & 6 & 4 \\
\hline Ratio of medians & 0.6 & 0.5 & 0.5 & 0.3 & Ratio of medians & 0.6 & 0.5 & 0.5 & 0.5 \\
\hline
\end{tabular}


Similarly, the 25th percentile of the "black distribution" corresponds to the 4th percentile of the "white distribution," which means that 25 percent of black children's families were as poor as the bottom 4 percent of white children's families. The 75th percentile of the black distribution corresponds to the 27th percentile of the white distribution, which means that 73 percent of white children's families were at least as wealthy as the top 25 percent of black children's families.

In addition, Table 17 reports a ratio of median incomes of black and white families. For example, in 1970 in Houston the median income of black children's families was only half the median income of white children's families. The picture is similarly bleak across all the cities and decadesthe median annual income of black children's families is only about one half the median annual income of white children's families. What is more, this ratio did not increase in any of the 14 cities over the 1970-2000 period. ${ }^{26}$ In fact, in 10 of the 14 cities the ratio decreased, meaning that the median income of black children's families decreased relative to the median income of white children's families. From 1970 to 2000, in San Francisco it decreased from 0.6 to 0.3 and in Chicago from 0.6 to 0.4 .

Where does the median income of black children's families fit into the income distribution of white children's families? In 2000, the situation was the "best" in New York, where the median of the black distribution corresponds to the 23rd percentile of the white distribution. Thus, in New York in 2000, 50 percent of black children's families had incomes below those of 77 percent of white children's families. The situation in 2000 was even worse in the rest of the cities-the median black distributions fell within only the 11th to the 17th percentiles of the white distributions.

For black children's families, the situation at the top and bottom quartiles of the income distribution is no better than in the middle. In 2000, the 75th percentile of the black distribution still corresponds to only the 33rd to the 43rd percentile of the white distribution. Perhaps even more sig-

\footnotetext{
${ }^{26}$ We also looked at ratios of various other percentiles of the two distributions. The results were the same-there is no change in ratios over the years.
}

nificant is that 25 percent of black children's families have incomes as low as those of the poorest 3 to 7 percent of white children's families. To sum up, there was no progress in the financial well-being of black children, relative to white children, between 1970 and 2000.

\section{CONCLUDING REMARKS}

More than 35 years after the Civil Rights Act, the economic status of black men is still much worse than that of white men. What is more, there appears to be virtually no progress of black men in the labor markets between 1970 and 2000. Some important indicators, such as the rate of those not in the labor force and relative annual earnings, have actually become worse. The social and family structure of the black population also experience negative changes.

This paper does not attempt to determine why there was stagnation, and even a reversal, of the economic progress of African Americans between 1970 and 2000. ${ }^{27}$ Instead, the main goal of this paper was to describe changes in various economic conditions of black men and their families at a city level. The second goal was to compare those changes across cities.

Although the overall picture is rather bleak, there are clear differences among the 14 cities studied. Industrial cities in the Midwest (Chicago, Detroit, Cleveland, and St. Louis) experienced more serious deterioration of their labor markets precisely because they used to be predominantly manufacturing cities. With the decline of the importance of manufacturing and a move to hightech and service industries, the black labor force, which was generally less educated, faced tough labor market conditions that resulted in high levels of unemployment. In addition, growing numbers of black men became discouraged about their job prospects and dropped out of the labor force completely. Family structure was disrupted as well as more and more black men chose not to marry. As a result, more black children are growing up in single-mother households and the economic

\footnotetext{
${ }^{27}$ Neal (2008) presents a short summary of possible explanations and a discussion of several related studies.
} 
well-being of black children has not improved since 1970.

Most eastern and western cities in the study showed declines similar to those in midwestern cities but of a somewhat lesser degree. Southern cities, on the other hand, did see some economic progress of black men, mostly between 1970 and 1980. These improvements, together with the reversal of economic progress in the Midwest, resulted in more uniform conditions for black men in 2000 than in 1970. Educational attainment of black men in the South, in particular, has increased dramatically compared with 1970.

Atlanta and Washington, D.C., stand out on a number of characteristics. In 2000, black men in those cities had the highest employment rates, as well as low rates of unemployment and those not in the labor force. They also had the highest proportions of those who went to college and those who had a bachelor's degree or higher. One of the reasons these two cities fared better is their industrial structure. Atlanta has a very vibrant mix of industries and never relied heavily on manufacturing. Washington, D.C., has a high proportion of service and stable government jobs. As a result, these cities have been able to attract high-skilled educated workers from other parts of the country.

Despite remarkable changes in society when it comes to racial acceptance and equality, the evidence presented in this paper reveals that significant racial disparities remain in education and labor market outcomes. A better understanding of underlying causes of the observed economic stagnation and a design of policies that would help improve the social and economic status of African Americans is an important topic for future research. 


\section{REFERENCES}

Altonji, Joseph G. and Blank, Rebecca M. "Race and Gender in the Labor Market," in Orley C. Ashenfelter and David Card, eds., Handbook of Labor Economics. Volume 3C. Chap. 48. Amsterdam: North Holland, 1999; pp. 3143-259.

Bound, John and Freeman, Richard B. "What Went Wrong? The Erosion of Relative Earnings and Employment among Young Black Men in the 1980s." Quarterly Journal of Economics, February 1992, 107(1), pp. 201-32.

Bound, John and Holzer, Harry J. "Industrial Shifts, Skill Levels, and the Labor Market for White and Black Males.” Review of Economics and Statistics, August 1993, 75(3), pp. 387-96.

Bound, John and Johnson, George. "Changes in the Structure of Wages in the 1980's: An Evaluation of Alternative Explanations.” American Economic Review, June 1992, 82(3), pp. 371-92.

Black, Dan A.; Kolesnikova, Natalia; Sanders, Seth and Taylor, Lowell J. "The Role of Location in Evaluating Racial Wage Disparity.” Working Paper 2009-043B, Federal Reserve Bank of St. Louis, September 2009, revised July 2010; http://research.stlouisfed.org/wp/2009/2009-043.pdf.

Black, Dan A.; McKinnish, Terra G. and Sanders, Seth G. "Does the Availability of High-Wage Jobs for LowSkilled Men Affect Welfare Expenditures? Evidence from Shocks to the Steel and Coal Industries." Journal of Public Economics, September 2003, 87(9-10), pp. 1921-42.

Calvó-Armengol, Antoni and Jackson, Matthew O. "The Effects of Social Networks on Employment and Inequality.” American Economic Review, June 2004, 94(3), pp. 426-54.

Charles, Kerwin Kofi and Luoh, Ming Ching. "Male Incarceration, the Marriage Market and Female Outcomes." Forthcoming in Review of Economics and Statistics.

Duncan, Greg J. and Hoffman, Saul D. "Welfare Benefits, Economic Opportunities, and Out-of- Wedlock Births among Black Teenage Girls.” Demography, November 1990, 27(4), pp. 519-35.

Holzer, Harry J. “Informal Job Search and Black Youth Unemployment.” American Economic Review, June 1987, 77(3), pp. 446-52.

Lichter, Daniel T.; LeClere, Felicia B. and McLaughlin, Diane K. "Local Marriage Markets and the Marital Behavior of Black and White Women.” American Journal of Sociology, January 1991, 96(4), pp. 843-67.

Moffitt, Robert A. "The Effect of Welfare on Marriage and Fertility: What Do We Know and What Do We Need to Know?” Discussion Paper No. 1153-97, Institute for Research on Poverty, December 1997; www.irp.wisc.edu/publications/dps/pdfs/dp115397.pdf.

Neal, Derek. "Why Has Black-White Skill Convergence Stopped?” in Eric Hanushek and Finis Welch, eds., Handbook of the Economics of Education. Volume 1. Chap. 9. New York: Elsevier, 2006, pp. 511-78.

Neal, Derek. "Black-White Labour Market Inequality in the United States," in Steven N. Durlauf and Lawrence E. Blume, eds., New Palgrave Dictionary of Economics. Second Edition. Hampshire, UK: Palgrave Macmillan, 2008.

Real Estate Center, Texas A\&M University. Metropolitan Population Data: Population and Household Data, U.S. Metropolitan Statistical Areas, MSA (1999 definition), 1970-present; http://recenter.tamu.edu/data/popm/.

Ruggles, Steven; Alexander, J. Trent; Genadek, Katie; Goeken, Ronald; Schroeder, Matthew B. and Sobek, Matthew. Integrated Public Use Microdata Series: Version 5.0 [Machine-readable database]. Minneapolis: University of Minnesota, 2010.

U.S. Census Bureau. Population Estimates Archives; www.census.gov/popest/archives/.

Western, Bruce. Punishment and Inequality in America. New York: Russell Sage Foundation, 2006. 


\section{APPENDIX 1: DATA AND VARIABLES DESCRIPTION}

Individual-level U.S. Census data were provided by the Integrated Public Use Microdata Series (IPUMS). See Ruggles et al. (2010).

\section{Educational Attainment}

The five education categories are did not finish high school; high school diploma (or GED); some college but no bachelor's degree; bachelor's degree; and higher than a bachelor's degree.

\section{Employment Status}

The three employment status categories are has a job, unemployed, and not in the labor force.

\section{Industry Variables}

Because of the relatively small size of the sample, it was necessary to combine Census-defined industries and occupations into larger groups. For consistency, the 1990 Census Bureau industrial classification scheme is used for all years. First, 11 industry categories were generated according to the Department of Labor's Standard Industrial Classification code: agriculture, forestry, and fishing; mining; construction; manufacturing; transportation, communications, and utility; wholesale trade; retail trade; finance, insurance, and real estate; service; public administration; and other. "Other" represents military personnel, temporary unemployed workers, and people with missing information. Then, wholesale trade and retail trade were combined into a category called "sales." Since only a very small fraction of people living in urban areas are employed in either agriculture, forestry, and fishing or mining, these two categories were combined with the "other" category. In the end, there are eight industrial categories.

\section{Marital Status}

The three marital status categories are married; separated, divorced, or widowed; and never married.

\section{Non-Migrant Indicator}

The non-migrant indicator variable was set equal to 1 if a person satisfied one of the following: born in Georgia and lives in Atlanta; born in Maryland and lives in Baltimore; born in Illinois and lives in Chicago; born in Ohio and lives in Cleveland; born in Michigan and lives in Detroit; born in Texas and lives in Houston; born in California and lives in Los Angeles; born in Tennessee and lives in Memphis; born in Mississippi and lives in Memphis; born in Louisiana and lives in New Orleans; born in New York and lives in New York; born in Pennsylvania and lives in Philadelphia; born in New Jersey and lives in Philadelphia; born in Missouri and lives in St. Louis; born in California and lives in San Francisco; born in Washington, D.C., and lives in Washington, D.C.; born in Maryland and lives in Washington, D.C.; and born in Virginia and lives in Washington, D.C. The indicator was set to 0 for all other persons.

\section{MSA Population}

MSA population data for 1970, 1980, 1990, and 1999 were downloaded from the Population database, Real Estate Center at Texas A\&M University and calculated based on U.S. Census data (http://recenter.tamu.edu/data/popm/). For consistency, the 1999 definition of MSAs was used.

\section{MSA Black Population}

County-level black population data for 1970, 1980, 1990, and 2000 were downloaded from the Population Estimates Archives, U.S. Census Bureau and aggregated into MSA-level data according to 1999 MSA definitions (www.census.gov/popest/archives/). 


\section{APPENDIX 2: ESTIMATION}

\section{Black-White Annual Earnings Gap}

A simple matching estimator was used to calculate for each metropolitan area $j$ the black-to-white ratio of annual earnings. Intuitively, black men were "matched" with white men based on their age and education. More precisely, let $b$ index black individuals and $w$ white individuals, and let $x_{i}$ be the ageeducation combination of individual $i$-for example, "31-year-old man with a high school diploma." Let $y_{i}$ be the annual earnings of individual $i$, and $E\left(y_{\{b, i\}} \mid x\right)$ the expected value of the annual earnings of that (black) individual given that his age-education combination is $x$. There are four education categories (see Appendix 1) and six age intervals: 25 to 30, 31 to 35, 36 to 40, 41 to 45, 46 to 50, and 51 to 55 years old.

Our interest then is in

$$
\text { Ratio }_{j}=\sum_{x=25}^{55}=\left[\frac{E_{j}\left(y_{\{b, i\}} \mid x\right)}{E_{j}\left(y_{\{w, i\}} \mid x\right)}\right] f_{b(x)},
$$

where $f_{b}(x)$ is the p.d.f. of age-education combinations among black workers in all cities. The equation is then directly estimated for each city by calculating the conditional means at each point in the distribution of covariates and then taking a weighted average. Observations with zero values are included in the calculations.

\section{Average Annual Weeks and Average Weekly Hours of Work}

One of the limitations of the data is that the 1970 Census asked respondents to select only among intervals of weeks and hours of work. Black et al. (2009) compute the average weeks and hours of work for those in the corresponding interval using 1980 Census data. In this paper, the values from Black et al. (2009) were used to make imputations for nonzero categories as follows:

\begin{tabular}{lclc} 
Interval & Imputed weeks & Interval & Imputed hours \\
\hline 1-13 weeks & 1.1 & 1-14 hours & 8.57 \\
14-26 weeks & 21.4 & 15-29 hours & 21.95 \\
27-39 weeks & 33.3 & $30-34$ hours & 30.64 \\
40-47 weeks & 43.4 & $35-39$ & 36.35 \\
48-49 weeks & 48.3 & 40 hours & 40 \\
50-52 weeks & 51.8 & 41-48 hours & 45.46 \\
& & 49-59 hours & 51.41 \\
& & 60 or more hours & 67.02
\end{tabular}

Then, for each city, the weighted-average annual weeks and weekly hours of work were calculated conditional on age and education. The distribution of the age-education combinations across all cities was used for weighting. Observations with zero values are included in the calculations. 
